\title{
A Survey of Cyclical Effects in Credit Risk Measurement Models
}

\author{
Linda Allen \\ Zicklin School of Business, \\ Baruch College, City University of New York \\ Anthony Saunders \\ Stern School of Business \\ New York University
}

May 2002.

\begin{abstract}
$\underline{\text { Abstract }}$
We survey both academic and proprietary models to examine how macroeconomic and systematic risk effects are incorporated into measures of credit risk exposure. Many models consider the correlation between the probability of default (PD) and cyclical factors. Few models adjust loss rates (loss given default) to reflect cyclical effects. We find that the possibility of systematic correlation between PD and LGD is also neglected in currently available models.
\end{abstract}




\section{A Survey of Cyclical Effects in Credit Risk Measurement Models}

It has long been recognized that banking is a procyclical business. That is, banks tend to contract their lending activity when business turns down because of their concern about loan quality and repayment probability. This exacerbates the economic downturn as credit constrained businesses and individuals cut back on their real investment activity. In contrast, banks expand their lending activity during boom periods, thereby contributing to a possible overheating of the economy that may transform an economic expansion into an inflationary spiral.

The proliferation of credit risk measurement models in banking may accentuate the procyclical tendencies of banking, with potential macroeconomic consequences. That is, the models' overly optimistic estimates of default risk during boom times reinforces the natural tendency of banks to overlend just at the point in the business cycle that the central bank prefers restraint. Moreover, if credit risk models are unduly pessimistic during recessions, then even the most expansionary monetary policy may not encourage banks to lend to obligors that are perceived to be poor credit risks. Recent BIS proposals to utilize credit risk models such as CreditMetrics as a basis for bank capital requirements may further accentuate the procyclical nature of banking unless the credit cycle and its effect on credit risk are appropriately recognized in the model structure. If banks are constrained by risk sensitive (as measured by internal models) capital allocations and regulatory requirements, they may be unable to lend during low points in the business cycle and overly encouraged to lend during boom periods. ${ }$ This is because risk sensitive

\footnotetext{
${ }^{1}$ To the extent that external credit ratings provide "through the cycle" estimates of default risk smoothed across the entire business cycle, it is the internal ratings-based approaches of the New Basel Capital Accord
} 
capital requirements (e.g., RAROC-based) increase (decrease) when estimates of default risk increase (decrease). Thus, if credit risk models overstate (understate) default risk in bad (good) times, then internal bank capital requirements will be too high (low) in bad (good) times, thereby forcing capital-constrained banks to retrench on lending during recessions and expand lending during booms. As stated by Andrew Crockett, the General Manager of the BIS, in a lecture on February 13, 2001: “[U]nderlying risk builds up as expansion and leverage continues, while apparent risk declines, with the rise in collateral values....[R]isk increases during upswings, as financial imbalances build up, and materialize in recessions." Concern about the macroeconomic implications of the procyclical nature of risk sensitive bank capital regulations has contributed to a delay until 2006 in adoption of the BIS proposals for the new Basel Capital Accord ${ }^{\text {D }}$

In this paper, we examine the treatment of cyclical factors in both academic and proprietary credit risk measurement models. ${ }^{0}$ In section 2 , we begin by discussing what is meant by procyclicality. We then divide our survey of credit risk measurement models into four sections. Section 3 surveys how various credit risk measurement models incorporate cyclical effects into the estimation of default probability (PD). In Section 4,

that is most likely to exacerbate the procylical tendencies of banking. However, if credit ratings behave procyclically [as shown by Ferri, Liu and Majnoni (2000), Monfort and Mulder (2000) and Reisen (2000)], then even the proposed standardized approach in the BIS New Capital Accord will exhibit cyclical fluctuations in capital requirements.

${ }^{2}$ Borio, Furfine and Lowe (2001) demonstrate that assessed risk falls during economic booms and rises during economic busts, although bank capital cushions lag the business cycle.

${ }^{3}$ For discussions of the procylical effects of regulatory and monetary policy across different countries, see BIS (2001).

${ }^{4} \mathrm{We}$ focus on firm sensitivity to systematic risk factors as an explanation for the correlations that may result in procyclical lending behavior. However, Berger and Udell (2002) offer a novel alternative hypothesis - the institutional memory hypothesis - which states that the abilities of loan officers to monitor risky loans deteriorates over the business cycle. Thus, credit assessment skills atrophy as the time since the last recession increases, thereby sowing the seeds of the next business downturn as loans are inappropriately extended and insufficiently monitored. Other behavioral explanations for procyclicality in default risk are "disaster myopia," "cognitive dissonance" and "herding behavior" because there is a tendency to underestimate extremely low probability, high loss events that do not conform to "prevailing beliefs." See Borio, Furfine and Lowe (2001). 
we describe models that examine the recovery rate (or one minus the recovery rate, the loss given default LGD) as a function of macroeconomic factors. In Section 5, we examine the correlation between PD and LGD. The procyclical flight to quality and the impact of systemic factors on the exposure at default (EAD) are examined in Section 6 and the paper concludes in Section 7.

\section{What is Procyclicality?}

It is almost axiomatic that defaults and credit problems would multiply in times of distressed macroeconomic conditions. Moreover, good economic times provide the rising tide that lifts even the shakiest of financial boats. Thus, ex post realizations of credit problems display clear procyclical patterns - increasing during recessions and decreasing during expansions. However, these patterns may be consistent with fixed portfolio loss distributions that have no systematic risk factors in either the PD, the LGD or the EAD. That is, realizations of credit losses (say, point A on loss distribution 1 in Figure 1) may increase during recessions, whereas economic expansions may, by definition, yield ex post realizations such as point B on the same loss distribution 1 .

\section{INSERT FIGURE 1 AROUND HERE}

In contrast to these shifts along a fixed distribution, procyclicality considers the shift in the entire loss distribution to reflect ex ante changes in credit risk exposure; shown in Figure 1 as the shift from loss distribution 1 in a "good" economy to loss distribution 2 in a "bad" economy. That is, if point A is a bad ex post realization of portfolio value on a stable loss distribution 1, then the portfolio's ex ante risk exposure is not affected by systematic risk factors. If, however, during good economic times we 
observe a value of portfolio losses corresponding to point B on loss distribution 1 and during bad economic times we observe a loss value corresponding to point $\mathrm{A}$ on loss distribution 2, then there is an ex ante procyclical shift in risk exposure. That is, the entire distribution of portfolio losses shifts in response to macroeconomic factors. Of course, since point A lies on both loss distributions, it is empirically difficult to disentangle ex ante procyclical shifts in risk from merely ex post realizations. This survey focuses on studies that attempt to measure procyclicality by modeling systematic shifts in the entire loss distribution in order to distinguish between the two observationally identical representations of point A in Figure 1.

\section{Cyclical Effects on the Probability of Default (PD)}

There is substantial anecdotal evidence to suggest that macroeconomic conditions impact the probability of default (PD). Fama (1986) and Wilson (1997) find cyclical PDs, especially in the case of economic downturns when PDs increase dramatically. Ferri, Liu and Majnoni (2000), Monfort and Mulder (2000) and Reisen (2000) find evidence that ratings agencies behave cyclically, particularly with respect to setting credit ratings for sovereign country debt. When using external credit ratings as a measure of credit quality, a distinction must be made between "point-in-time" and "through-thecycle" risk assessment. This is most relevant in the context of interpreting external credit ratings that are designed to be "through-the-cycle" assessments of the default probability over the life of the loan. Thus, the PD is estimated at the worst point in the cycle expected to prevail over the debt maturity time horizon. assessments of PD respond to changes in cyclical conditions. Crouhy, Galai and Mark

\footnotetext{
${ }^{5}$ Most ratings are reviewed at least once a year to update their accuracy.
} 
(2001) contend that "through-the-cycle" ratings are a more appropriate input into lending decisions, whereas "point-in-time" ratings are more appropriate for the purposes of capital allocation.

Bangia, Diebold and Schuermann (2000) and Nickell, Perraudin and Varotto (2000) find evidence of macroeconomic and industry effects on rating transitions. That is, ratings downgrades and defaults are more likely during downturns in economic activity. Carey (1998) documents significant differences in default rates for "good" years, as compared to "bad" years. Falkenheim and Powell (1999) find that 15 out of 21 industries in Argentina have positively correlated PDs.

\section{INSERT TABLE 1 AROUND HERE}

Table 1, reproduced from Altman and Brady (2001), shows the apparent relationship between PD and macroeconomic conditions. Default rates exceeded $10 \%$ in the recession years 1990-1991. Moreover, the economic downturn in the year 2000 corresponded to significant increases in default rates as compared to the low default rates experienced during the 1993-1998 boom period. While suggestive, the results in Table 1 cannot distinguish between the two possibilities shown in Figure 1 - an actual increase in ex ante PD during recessions (i.e., a shift from loss distribution 1 to loss distribution 2 in Figure 1) as opposed to simply an increase in the ex post realization of defaults during bad times (i.e., a shift from point B to point A along a fixed loss distribution 1). That is, it is unclear whether the default rates in Table 1 are indicators of the ex ante risk of default. If so, they would indicate the existence of a cyclical component in PD.

\footnotetext{
${ }^{6}$ Most studies utilize US data to estimate credit risk exposure. It is unclear whether the results are generalizable for other countries, particularly those with different bankruptcy regulations. For example, Korea has higher bank closure rates than Japan, and therefore Korean banks have recovered more quickly than have Japanese banks from the effects of bad loans in their portfolios.
} 
Alternatively, however, the default rates in Table 1 may simply be ex post realizations of defaults that are, by definition, in the upper (lower) range of the loss distribution during bad (good) years. Moreover, Borio, Furfine and Lowe (2001) point out that the observed cyclicality in default rates may be an artifact of timing in a mean reverting PD function. That is, the "aging effect" stipulates that it takes around three or four years after origination for defaults to be realized [see Altman and Kishore (1996)]. If more debt instruments originate during cyclical upturns than during downturns, then a relatively large number of bonds will reach "default age" three or four years after the end of the expansionary period. Even if a fixed percentage of these bonds defaults, the absolute number of defaults will rise. This increase in defaults is likely to coincide with a cyclical decline in economic activity, thereby creating a spurious procyclical pattern.

To distinguish between the two alternatives shown in Figure 1, we must estimate the PD conditional on macroeconomic factors. It is to this task that we now turn. We first describe academic models, then proprietary models, and finally, the impact of cyclical factors on the BIS capital proposals.

\subsection{Academic Models}

Modern methods of credit risk measurement can be traced to two alternative branches in the asset pricing literature of academic finance: an options-theoretic structural approach pioneered by Merton (1974) and a reduced form approach utilizing intensity-based models to estimate stochastic hazard rates, following a literature pioneered by Jarrow and Turnbull (1995), Jarrow, Lando, and Turnbull (1997), and Duffie and Singleton $(1998,1999)$. These two schools of thought offer differing methodologies to accomplish the central task of all credit risk measurement models - 
estimation of default probabilities. The structural approach models the economic process of default, whereas reduced form models decompose risky debt prices in order to estimate the random intensity process underlying default.

\subsubsection{Structural Models of Cyclical Effects on PD}

Structural models measure the cyclical impact on PD by incorporating systemic risk factors into the specification of the stochastic asset diffusion process. Since default occurs in a structural model when the market value of assets falls to the default point (set equal to the face value of debt), then the PD depends on the distance between the market value of assets and the default point during the credit horizon period (usually assumed to be one year). The default region is shown in Figure 2 as the shaded area in which the market value of assets is less than the face value of debt. Forecasting the distribution of asset values in one year's time is therefore critical to the determination of PD in a structural model.

\section{INSERT FIGURE 2 AROUND HERE}

In this section, we focus on the impact on PD of systematic fluctuations in asset values. However, the existence of procyclical shifts in the default point (i.e., leverage amounts) may also induce cyclical PDs. That is, when economic conditions deteriorate, shareholders may be more likely to extract concessions from debtholders that lower the default point, say, from $B_{1}$ to $B_{2}$ in Figure 2. These possible deviations from absolute priority occur when liquidation costs are very high. ${ }^{\mathrm{D}}$ Thus, debtholders may be willing to

\footnotetext{
${ }^{7}$ The two approaches can be reconciled if asset values follow a random intensity-based process, with shocks that may not be fully observed because of imperfect accounting disclosures. See Duffie and Lando (2001) and Zhou (2001).

${ }^{8}$ For example, the boundary will become stochastic if there is liquidation cost to asset values. This gives borrowers the power to renegotiate; see Longstaff and Schwartz (1995). Also Leland (1994), Anderson, Sundaresan, and Tychon (1996), and Mella-Barral and Perraudin (1997) allow for debt renegotiations (i.e., renegotiations of the debt boundary value, or $B$ in the context of a structural model).
} 
reduce the face value of the debt so as to avoid the high deadweight costs of bankruptcy and liquidation of assets. If lenders are more likely to renegotiate debt in recessions than during expansions ${ }^{2}$ and if asset volatilities are unchanged, then decreases (increases) in economic activity would coincide with decreases (increases) in PD, as shown in Figure 2 by the smaller shaded area under default point $\mathrm{B}_{2}$ as compared to the shaded area under point $\mathrm{B}_{1} .10$ However, if asset volatility increases (decreases) during recessions (expansions), there would be a procyclical pattern in PD such that PD increases during recessions and decreases during expansions. Which of these two effects dominates is a matter for empirical investigation, although the anecdotal evidence suggests that the asset volatility effect dominates the effect of a cyclical shift in the default point. In the remainder of this section, we examine academic studies of the relationship between macroeconomic conditions, fluctuations in asset values and default probabilities. 11 The consensus in this branch of the literature is that asset values and PDs tend to be positively correlated across obligors. Moreover, PD is time-varying and regime dependent. Firm interdependence (such as industry effects) can produce correlated PDs. In addition, cyclical effects in asset valuations and shifts in regime (due to structural, regulatory, or economic factors) impact $\mathrm{PD}$. There is also evidence that default correlations are higher for low credit quality firms than for highly rated firms. We turn now to a brief survey of some of the papers that comprise this literature.

\footnotetext{
${ }^{9}$ Lenders may be more amenable to debt renegotiation during recessions than in expansions because they themselves may be experiencing financial distress, or in order to avoid the liquidation of the borrowing firm's assets just at the time in the business cycle that asset values are depressed.

${ }^{10}$ However, recovery rates would fall during recessions since lenders are induced to make concessions that reduce the payout on the debt in the event of eventual default. Thus, shifts in the default point may induce procyclical shifts in LGD; see Section 4.

${ }^{11}$ We discuss cyclical shifts in the default point in Section 6 in the context of procyclicality in EAD and endogenous leverage ratios.
} 
Fridson, Garman and Wu (1997) find a relation between macroeconomic conditions and PD. In particular, they find that as real interest rates increase, asset values decrease, thereby increasing the estimate of PD in a structural model. They find a two year lag in the interest rate effect because of the existence of a cushion of cash reserves or a lag until debt payment date that may allow even insolvent firms to delay default. Since risk-free interest rates are negatively are negatively correlated with the market index (Barnhill and Maxwell (1999) report a correlation coefficient of -0.33), the Fridson, Garman and Wu (1997) result implies a positive correlations between PD and the overall market index.

Barnhill and Maxwell (1999) simulate asset distributions that are conditional on macroeconomic conditions. 12 They find that systematic risk exposure increases as credit quality deteriorates. Moreover, since average credit quality declines as economic conditions deteriorate, there is an increased sensitivity to macroeconomic conditions in downturns. Table 2 shows their results. The average level of systematic risk (as measured by the equity beta) increases monotonically as credit quality (measured by simulated external credit ratings ${ }^{13}$ ) deteriorates. Moreover, the beta (i.e., the systematic risk coefficient) for firms with high volatility (i.e., higher than average historical volatility in stock price) is always greater than or equal to the beta for low volatility firms. Thus, if external credit ratings are accurate indicators of PD, Barnhill and

\footnotetext{
${ }^{12}$ Although Barnhill and Maxwell (1999) incorporate a cyclical factor into their simulations of transmission matrices (including PD), they assume that recovery rates are stochastic with a known mean (34\%) and standard deviation (25\%) unrelated to macroeconomic factors. This recovery rate distribution is taken from Altman and Kishore (1996).

${ }^{13}$ Barnhill and Maxwell (1999) simulate debt/equity ratios, which are then mapped into a simulated bond rating such that the bond rating indicates declines in quality as the debt ratio increases. This is equivalent to assuming a constant volatility for the value of the firm. Testing their simulations against actual US bond data over the period 1993-1998, they find that their model performs well for credit ratings Aaa through $\mathrm{Baa}$, but poorly for the Caa/C category.
} 
Maxwell's simulation results are consistent with the existence of a cyclical effect on PD, particularly for poor credit quality firms.

\section{INSERT TABLE 2 and FIGURE 3 AROUND HERE}

Indeed, the cyclical effect is stronger when the economy enters into a recession.

Figure 3 shows how the systematic risk factors impact the PD in a structural model.

Panel A (B) shows the stochastic process determining asset values over the credit horizon for a low volatility/high credit quality (high volatility/low credit quality) firm. A recession tends to reduce asset values for both firms, thereby increasing the area of the default region, and thus increasing the PD. However, the downward shift in asset values is greater for the high volatility/low credit quality firm, demonstrating that the procyclical impact on PD is stronger than for the low volatility/high credit quality firm.

Gersbach and Lipponer (2000) also find that default correlations increase (decrease) as credit quality deteriorates (improves). Following from their assumption that the default distribution is derived from the jointly log normal asset distributions of each pair of firms, the correlation between default probabilities is always less than the correlation between asset values. ${ }^{14}$ Table 3 shows these results for asset return correlations assumed to be $40 \%$ and $80 \%$. Default correlations increase monotonically as PD increases for both levels of asset correlation. Moreover, default correlations under the $80 \%$ asset correlation assumption always exceed the default correlations under the $40 \%$ asset correlation assumption.

\footnotetext{
${ }^{14}$ Although the precise functional form presented by Gersbach and Lipponer (2000) for the PD correlation stems from the counterfactual assumption of log normally distributed asset returns, we can offer some economic intuition for the result that default correlations are less than asset correlations. Joint defaults occur only if the assets of both firms fall below each firm's debt obligations. Thus, even if the two firms have positively correlated assets, the default of one firm may not coincide with asset returns in the other firm that are low enough to cause default in the other firm.
} 


\section{INSERT TABLE 3 AROUND HERE}

Gersbach and Lipponer (2000) also examine the impact of macroeconomic shocks (measured as interest rate shocks) on default correlations for loan portfolios, holding constant both asset correlations and default probabilities. $\frac{15}{\text { They find that }}$ macroeconomic shocks increase positive default correlations, thereby engendering procyclical effects as portfolio diversification benefits decline (i.e., both PD and default correlations increase) in economic downturns. This procyclical effect is significant - on the order of $30 \%$ of the increase in credit risk when initial PD is 5\% for initial default correlations of $14.6 \%$. This result is supported by a paper by Collin-Dufresne and Goldstein (2001) that focuses on the relationship between the market value of assets and the default point. Thus, as the default risk-free rate increases, asset values decline, thereby causing an increase in PD, or a positive correlation between changes in default risk-free interest rates and default risk.

Zhou (2001) uses a first passage time model to ascertain the time until the asset value reaches the default point (assumed to be fixed at the value of short term liabilities plus one half of all long term liabilities); i.e., the expected time until default. Zhou's (2001) results are consistent with those of the previously cited studies in that he finds stronger macroeconomic effects for low credit quality firms than for high credit quality firms. Since the credit quality of the firm is itself dynamic, Zhou (2001) contends that the cyclical effects on PD are also dynamic. Using an assumption that the correlation

\footnotetext{
${ }^{15}$ Gersbach and Lipponer (2000) assume a fixed recovery rate that is a percentage of the outstanding debt obligation. Their results present a lower bound of the impact of procyclicality because all of the fixed terms (PD, asset correlations and LGD) actually have procyclical components.
} 
between asset values is $40 \%, \frac{16}{Z h o u ~(2001) ~ f i n d s ~ t h a t ~ d e f a u l t ~ c o r r e l a t i o n s ~ i n c r e a s e ~ a s ~ t h e ~}$ time to maturity increases 17 and as the credit quality decreases. See Table 4 for a summary of these results. However, the observed pattern in default correlations may or may not be a function of business cycle effects, as Zhou (2001) finds evidence that default (particularly for short maturity debt) is idiosyncratic and related to unexplained jumps in the asset diffusion process.

\section{INSERT TABLE 4 AROUND HERE}

Crouhy, Galai and Mark $(2000,2001)$ also find that the most speculative risk classifications' default probabilities are most sensitive to shifts in macroeconomic conditions. That is, PD correlations are highest for low quality firms. In particular, they find the existence of an asymmetric procyclical impact on PDs such that default probabilities increase significantly during economic downturns, but do not decrease significantly during economic upturns. That is, a recession is sufficient to force many marginal firms into default, thereby causing large increases in both PDs and default correlations for these firms. In contrast, an economic boom is insufficient to lift many of these firms' credit quality, thereby reducing the correlation across firm PDs. Stated simply, business recovery is driven more by firm specific factors, whereas business failure is more systematic.

\footnotetext{
${ }^{16}$ The $40 \%$ estimate of asset correlations approximates the correlation in equity values, adjusted for leverage. However, this relationship holds only for high credit quality (generally, low leverage) firms. Jarrow, Van Deventer, and Wang (2002) show that structural models perform quite poorly for highly leveraged firms.

${ }^{17}$ Using a standard Merton options pricing model, Zhou (2001) presents a similar term structure of default correlations (i.e., default correlations increase as the time to maturity increases), although the Merton model obtains significantly lower estimated default correlations than does the Zhou (2001) first passage time model. This is because the Merton model ignores the possibility of early default and only focuses on default at the fixed credit time horizon (the debt's maturity date), whereas the first passage time model estimates the probability that asset values will fall below the default time at any time horizon.
} 
Longin and Solnik (2001) also find evidence of asymmetric procyclicality.

Using extreme value theory, they find increases in correlations across international equity markets during bear markets, but not in bull markets. Since structural models use equity prices to estimate PD, Longin and Solnik's (2001) results imply that default correlations should increase during economic downturns, but not necessarily during economic upturns.

Erlenmaier and Gersbach (2001) may resolve some of the controversy about whether default correlations are directly or inversely related to PD. Using a structural model and a fixed, exogenous LGD, they divide the correlation effect into a skewness effect (SE) and a distance-of default effect (DDE). That is, systematic risk factors that increase PD levels tend to move the observations into the extreme portions of the default distribution that are more highly skewed; that is, there is more divergence among the PDs for individual firms. ${ }^{19}$ Since the greater the skewness, the less information is revealed about the correlated underlying firm asset returns, then increases in skewness result in decreases in default correlations. Thus, the relationship between default correlations and the $\mathrm{PD}$ is shaped like an inverted $\mathrm{U}-$ it increases for the region up until $\mathrm{PD}=50 \%$ and then decreases thereafter. ${ }^{0}$ However, there is a countervailing distance-of default effect (DDE), which is monotonically decreasing as PD increases. That is, if one firm's PD increases and the other firm's PD stays the same, it is tautological that both firms' PDs will diverge and the correlation between their PDs will decrease. The observed

\footnotetext{
${ }^{18}$ Longin and Solnik (2000) do not study PD and LGD correlations directly. However, if LGD is also a function of equity prices, then their results are consistent with increases in LGD correlation during bear markets, but not in bull markets.

${ }^{19}$ Alternatively, if extreme regions of the default distribution obtain from systematic risk factors that make idiosyncratic risk less important, then increases in skewness would result in increased default correlation. This possibility is considered in Section 4 in the context of endogenous LGD.

${ }^{20}$ Since a PD>50\% is not economically reasonable, Erlenmaier and Gersbach (2001) only consider the upward sloping region of the skewness effect.
} 
relationship between the level of PD and the default correlation nets the SE and the offsetting DDE. Based on their simulation results, Erlenmaier and Gersbach (2001) contend that the SE effect dominates the DDE effect in the relevant range. Therefore, default correlations tend to increase as PD increases.

Erlenmaier and Gersbach (2001) also observe that the impact of cyclical effects on PD levels and correlations is only part of the picture. They find that the standard deviation of default rates vary throughout the business cycle. That is, extreme economic conditions (booms and busts) are characterized by two and three fold increases in portfolio standard deviation in addition to shifts in default correlations.

\subsubsection{Reduced Form Models of Cyclical Effects on PD}

Reduced form models decompose observed credit spreads to detect the term structure of default probabilities. Thus, reduced form models do not examine the structural factors leading to default. Rather PD is modeled using the stochastic intensity function that best fits the yield curve data, as shown in Figure 4. The credit spread, denoted CS, is the premium included in the yield on zero coupon, risky debt over the yield on same duration/maturity, zero coupon, default risk-free debt. If CS is a pure risk premium for credit risk exposure, 21 then risk neutral security pricing implies that $\mathrm{CS}=$ PD $x$ LGD. In this section, we will discuss how reduced form models decompose the credit spread in order to solve for PD. In Section 4.1.2, we decompose the credit spread in order to solve for LGD.

\footnotetext{
${ }^{21}$ This may not be the case if there is a liquidity risk premium or other noise in debt prices such that the yield spread is not a pure credit risk premium. See discussion in Chapter 5 of Saunders and Allen (2002).
} 


\section{INSERT FIGURE 4 AROUND HERE}

Duffie and Singleton (1998) model an intensity function with both idiosyncratic and systematic factors. The model can incorporate multiple systematic factors. The cyclical effect is observed in the correlated Poisson arrivals of randomly sized jumps in default intensities. Moreover, Duffie and Singleton (1999) and Lando (1998) model the cyclical component as a function of the short term risk-free interest rate (where interest rates are inversely correlated with the market index). However, this specification does not obtain estimates of PD that exhibit the cyclicality in PDs observed in anecdotal evidence.

Geyer, Kossmeier and Pichler (2001) apply the Duffie and Singleton (1999) model to European government bond spreads, defined to be the spread over German sovereign bonds (assumed to be default risk-free) on sovereign government bonds issued by Austria, Belgium, Italy, The Netherlands and Spain. They find strong evidence of a global systematic risk factor as well as idiosyncratic country risk factors for each issuer over the period 1999-2000. The global risk factor represents the average level of yield spreads across all countries and across all maturities. Table 5 shows that Belgium, Italy and Spain are more strongly related to the global factor than are Austria and the Netherlands.

\section{INSERT TABLE 5 AROUND HERE}

Das, Freed, Gang and Kapadia (2001) and Das, Fong and Geng (2001) use an intensity-based model to detect cyclical default probabilities. Their results parallel those of Crouhy, Galai and Mark $(2000,2001)$ in that PD correlations among US non-financial public firms over the period January 1987 to October 2000 are estimated to be higher 
when markets move down (i.e., PD levels are high on average) in contrast to when markets move up (PD levels are low). Moreover, Table 6 shows that their results differ from many of the papers presented in Section 3.1.2 [e.g., Barnhill and Maxwell (1999), Gersbach and Lipponer (2000), Erlenmaier and Gersbach (2001), Crouhy et al. (2000, 2001) and Zhou (2001)] in that default correlations increase as credit quality improves. That is, PD across high credit quality firms may be higher at times than for low credit quality firms because high quality firms have less idiosyncratic risk in their balance sheets than do low quality firms. Moreover, Das, Freed, Geng and Kapadia (2001) hypothesize that PD correlations fluctuate over time. They use US bond data over the period 1987-2000 to estimate a switching of regression regimes model that endogenizes the time period cut-off points. The time period regimes do not conform to business cycles, suggesting that fluctuations in PD correlations are not necessarily cyclical. Moreover, the highest correlation is found for the earliest period in their sample: January 1987 - April 1990, a period that includes both recession and non-recession years. Das, Fong and Geng (2001) show that ignoring these time-varying correlations in default probabilities results in substantial underestimates of credit risk exposure.

\section{INSERT TABLE 6 AROUND HERE}

Jarrow and Yu (2001) consider a doubly stochastic Poisson process. 2 The default intensity depends on macroeconomic factors and an interdependence term linking firms across industries and sectors. Thus, correlations across PDs arise because of both a systematic risk factor and a counterparty risk factor that is essentially an exposure to other firms' idiosyncratic risk. This counterparty risk may emanate from exposure to

\footnotetext{
${ }^{22}$ In a doubly stochastic Poisson process (also known as a "Cox process"), the intensity of default (i.e., the PD per unit of time) is itself a stochastic process that depends on a set of macroeconomic state variables.
} 
suppliers as in vertically integrated manufacturing processes (e.g., GM's exposure when Delphi's workers went on strike in 1998), access to capital (e.g., the Asian financial crisis stemming from nonperforming loans to several industrial conglomerates), and contagion effects (e.g., the impact of Long Term Capital Management's potential default on its bankers). Jarrow and Yu (2001) find that consideration of counterparty risk factors results in estimates of PD that exhibit the observed clustering in defaults found during economic downturns.

Bakshi, Madan and Zhang (2001) estimate a three factor credit risk model that depends on systematic (observable economic) factors and firm-specific distress variables (such as leverage, book-to-market, profitability, lagged credit spread, and scaled equity price). The systematic factors are the default risk-free interest rate and its stochastic long run mean. ${ }^{23}$ Bakshi, Madan and Zhang (2001) find that the interest rate factors are important determinants of the credit spread. Moreover, the idiosyncratic factors representing firm distress (particularly the leverage and book-to-market variables) reduce out-of-sample fitting errors for a sample of US corporate bonds (without embedded options) issued from January 1973 to March 1998. However, the model performs better for high credit quality bonds than for higher risk bonds.

\subsection{Proprietary Models}

KMV offers a proprietary model based on the options theoretic structural approach. Estimates of default correlations range from $0.2 \%$ to $15 \%$. However, default

\footnotetext{
${ }^{23}$ Bakshi, Madan and Zhang (2001) estimate their model using monthly data. Two interest rate factors are used to reduce errors in measuring the default risk-free rate. They use daily quotes on three month Treasury STRIPS to calculate the daily pricing error (as compared to the model price using a term structure model). For each month, they then construct a smoothed parameter vector that minimizes the root meansquared percentage pricing error. Thus, both the market price and the smoothed mean value are used in the reduced form model.
} 
correlations have increased over time as the overall level of leverage has increased. KMV considers the systematic factors impacting default correlations using a three level approach. The first level incorporates a composite market risk factor. The second level includes an industry and country risk factor. The third level contains regional factors (Europe, North America, Japan, Southeast Asia, Australia/New Zealand) and sectoral indicators (interest sensitive, extraction, consumer non-durables, consumer durables, technology, medical services, and other). The factor loadings (i.e., systematic risk sensitivities) for any individual firm for each of the factors in the three level model are estimated using asset variances obtained from the options theoretic model. Then the factor loadings are used to calculate covariances for each pair of firms. Finally, the correlation coefficient is calculated using the standard formula of scaling down the covariance by the product of the two firms' standard deviations. However, KMV does not explicitly consider a cyclical factor in their estimation of empirical EDF scores, although the regional and sectoral factors are impacted by macroeconomic conditions.

Once the covariance between each pair of firms' equity returns is calculated, it is combined with each firm's KMV EDF score in order to obtain an estimate of the correlation coefficient. The empirical EDF combines the option theoretic approach with the use of an empirical database representing the historical asset distribution function. 4 That is, the distance to default is calculated using the asset value and asset volatility obtained from the options pricing model. Then the one-year empirical EDF is calculated by referring to the percentage of defaults in a sample of firms with the same initial distance to default. The empirical EDF is not a risk-neutral PD because it uses actual default experience that includes a risk-adjusted required rate of return; therefore, the

\footnotetext{
${ }^{24}$ Merton's (1974) assumption of normally distributed assets results in widely erroneous model estimates.
} 
empirical EDF is biased downward. To transform the empirical EDF into the higher riskneutral PD (denoted QDF by KMV), a single index model is estimated to calculate the return to systematic risk. The options pricing model is then re-estimated, adjusted for the systematic risk premium over the risk-free rate.

CreditMetrics is a structural approach, proprietary Value at Risk (VaR) model that is based on credit transition matrices that estimate the probability of credit migration downward to default or to another credit rating. Estimates of default correlations range from $0.13 \%$ to $3.3 \%$. The credit transition matrix can be conditioned on cyclical factors using a shift term called the credit cycle index, the $Z$ factor, modeled as a shift term that shifts the entire return distribution down (up) when economic conditions deteriorate (improve). Finger (1999) shows that the credit cycle index is obtained by regressing default rates for speculative grade ( $\mathrm{Ba} \&$ below) bonds on: the credit spread between Aaa and Baa, 10 year US Treasury bond yields and growth rates in the CPI and GDP. Kim (1999) backtests the model and finds that incorporating cyclical factors reduces errors by $30 \%$ compared to the historical average transition matrix. Thus, the conditional PD that reflects the loan's sensitivity to macroeconomic factors appears to outperform the unconditional PD, suggesting that cyclical factors are important determinants of PD. This is further supported by Belkin, Suchower and Forest (1998) who estimate the systematic risk premium incorporated in a simulated loan portfolio consisting of 10,000 loans with the same credit ratings and with credit migration correlations of $25 \%$. Table 7 shows their results. The systematic risk premium increases steadily as credit quality (measured by credit rating) declines, ranging from 4.6 basis points for Aaa rated loan 
portfolios to 839 basis points for Caa rated loan portfolios, thereby implying an increase in the cyclical component of credit spreads as the credit quality declines.

\section{INSERT TABLE 7 AROUND HERE}

Each cell in the credit transition matrix shows the probability that a particular obligor, rated at a given grade at the beginning of the period, will move to another rating by the end of the period. CreditPortfolio View, using the structural approach, asserts that the probability of downgrades (upgrades) increases in bad (good) economic periods.

Thus, the conditional transition matrix represents the migration probabilities for each cell, conditional on the state of the macroeconomy that is expected to prevail at the credit horizon. The model uses a distributed lag model to forecast macroeconomic conditions based on both fundamental macroeconomic variables and idiosyncratic risk factors. Each transition probability is computed as a function of the macroeconomic forecast and diffused through the migration matrix. Different conditional transition matrices can be estimated for different credit horizons corresponding to fluctuations in macroeconomic

conditions. ${ }^{2.5}$ For example, Saunders and Allen (2002) show how the unconditional credit transition matrix (reproduced in Table 8 for only four credit migrations: $\mathrm{C}$ to $\mathrm{A} ; \mathrm{C}$ to $\mathrm{B} ; \mathrm{C}$ to $\mathrm{C}$; and $\mathrm{C}$ to default) can be transformed into a conditional transition matrix for a cyclical downturn. As shown in Table 8, the probability of transition from an initial rating of $\mathrm{C}$ to default has increased from $15 \%$ to $17.4 \%$ as a result of the deterioration in economic conditions. Interestingly, the probability of an upgrade from $\mathrm{C}$ to $\mathrm{A}$ has also increased (from $1 \%$ to $1.24 \%$ ) because credit upgrades during cyclical downturns are more likely to result from idiosyncratic firm specific factors. Thus, recessions increase

\footnotetext{
${ }^{25}$ Although CreditMetrics and CreditPortfolio View can incorporate cyclical effects into estimates of PD, this is not done for LGD.
} 
the likelihood of extreme outcomes and decrease the likelihood that credit quality will remain substantially unchanged.

\section{INSERT TABLE 8 AROUND HERE}

Credit Risk Plus stands in direct contrast to CreditMetrics and CreditPortfolio View in its objectives and its theoretical foundations. CreditMetrics and CreditPortfolio View seek to estimate the full VaR of a loan or loan portfolio by viewing rating upgrades and downgrades and the associated effects of spread changes in the discount rate as part of the VaR exposure of a loan. Credit Risk Plus is an intensity-based model that views spread risk as part of market risk rather than credit risk. As a result, in any period, only two states of the world are considered - default and non-default - and the focus is on measuring expected and unexpected losses rather than expected value and unexpected changes in value (or VaR) as under CreditMetrics or CreditPortfolio View. In the extended Credit Risk Plus model, there are three types of uncertainty: (1) the uncertainty

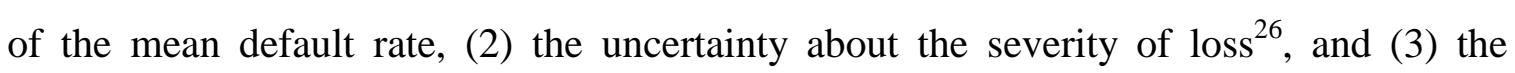
uncertainty about the mean default rate itself (modeled as a gamma distribution). Credit Risk Plus derives a closed form solution for the loss distribution by assuming that these types of uncertainty are all independent. 7 Thus, Credit Risk Plus distinguishes between ex ante procyclicality and ex post realizations as shown in Figure 1 by estimating shifts in the mean of the loss distribution.

Cyclical factors are incorporated into Credit Risk Plus by allowing the mean default rate itself to vary over time or over the business cycle. For example, in economic expansions, the mean default rate will be low; in economic contractions, it may rise

\footnotetext{
${ }^{26}$ Credit Risk Plus does not adjust the loss severity for systematic risk exposure.

${ }^{27}$ The assumption of independence may be violated if the volatility in mean default rates reflects the correlation of default events through interrlated macroeconomic factors.
} 
significantly (e.g., a shift from loss distribution 1 to loss distribution 2 in Figure 1). Credit Risk Plus models find that default correlations are highest for the lowest quality firms, supporting earlier academic results. However, the Credit Risk Plus model does not consider the possibility that cyclical factors affect all three sources of uncertainty (i.e., the mean PD, the LGD and the uncertainty around the mean PD). That is, only a shift in means is considered; not a shift in the standard deviation, skewness or kurtosis of the distribution as might be observed in the shift from loss distribution 1 to 2 in Figure 1.

Kamakura's Risk Manager (KRM) is a reduced form proprietary model that uses bond prices, equity prices, and accounting data in order to solve for a default intensity function. The default intensity process is modeled as a function of stochastic default-free interest rates, liquidity factors, and lognormal risk factors, such as a stochastic process for the market index. Thus, Kamakura models cyclical factors using an equity price index. Macroeconomic conditions therefore impact PD through the systematic risk component of equity prices.

KRM is based on Jarrow (2001). Credit spreads are decomposed into PD and LGD by the use of both debt and equity prices in order to better separate the default intensity process from the loss recovery process. ${ }^{28}$ The default hazard rate is modeled as a function of stochastic default-free interest rates, liquidity factors, and lognormal risk factors, such as a stochastic process for the market index. KRM is benchmarked using credit spreads or bond prices, equity prices, and accounting data over a period of 1962 to 1990, with out of sample forecasting over 1991 to 1999 . The five explanatory variables, denoted $\mathrm{X}(\mathrm{t})$, used to parameterize the system are: $(1)$ return on assets $=($ net

\footnotetext{
${ }^{28}$ Jarrow (2001) makes the interesting point that, prior to this work, structural models used only equity prices, eschewing debt prices as too noisy, whereas reduced form models used only debt prices. This is claimed to be the first model to combine both debt and equity prices in an intensity-based format.
} 
income $) /($ total assets $) ;(2)$ leverage $=($ total liabilities $) /($ total assets $) ;(3)$ relative size $=$ (firm equity value)/(total market value of the NYSE and AMEX); (4) excess return (monthly) over the CRSP NYSE/AMEX index return; and (5) monthly equity volatility.

Reduced form models are subject to error because observed credit spreads incorporate noise and other factors such as liquidity risk premiums in addition to pure credit risk premiums. The liquidity factor is modeled in KRM as a convenience yield, such that when the supply of a particular issue is tight (i.e., when one cannot buy the issue because asking prices are high and special rates on repurchase agreements are low), then there is a positive convenience yield incorporated into bond spreads. Alternatively, when there is a glut of a particular issue (i.e., in times of credit crises and high market volatilities, when some bonds can only be sold at discount prices), then there is a negative convenience yield incorporated into bond spreads. The Jarrow model measures liquidity risk by estimating these convenience yields implicit in bond prices.

Recovery rates are modeled as a fixed percentage of debt prices just prior to default, with equity prices used to determine that percentage. ${ }^{2 .}$ That is, since the equity price is not a function of either the liquidity premium or the LGD and the bond price is a function of both variables (as well as others), then the use of both price series can be used to separate out the LGD from the PD. Prices can be expressed as:

$$
\begin{gathered}
\text { Bond Prices: } \quad B=B[t, T, i, \lambda(t, X(t)), \delta(t, X(t)), \gamma(t, T, X(t)), \mu, S(t, X(t))] \\
\text { Equity Prices: } \quad \xi=\xi[t, T, i, \lambda(t, X(t)), \mu, S(t, X(t))]
\end{gathered}
$$

where $t$ is the current period; $T$ is the bond's time to maturity; $i$ is the stochastic defaultfree interest rate process; $\lambda(t, X(t))$ is the default intensity process, i.e., the risk neutral

\footnotetext{
${ }^{29}$ Equity prices consist of a stream of dividend payments plus a "liquidating dividend" which is the payment to the equity holder in the event of default on the firm's debt. Since equity represents the residual claim on the firm's assets, the implied value of this liquidating dividend can be used to solve for the bondholders' LGD.
} 
$\mathrm{PD} ; \delta(t, X(t))$ is the recovery rate ( $1-\mathrm{LGD}) ; \gamma(t, T, X(t))$ is the liquidity premium; $\mu$ is a stock market bubble factor; and $S(t, X(t))$ is the liquidating dividend on equity in the event of bond default. Thus, KRM is the only proprietary model that incorporates cyclical factors into both PD and LGD.

\subsection{The BIS Basel Capital Accord}

The January 2001 proposals for the new Basel Capital Accord specify a constant default correlation of $20 \%$ in the Internal Ratings-Based Approach models. In the November 2001 proposed modifications, this specification was changed and calibrated to a range between 10-20\%. The November 2001 proposals specify an inverse relationship between the PD and default correlations (denoted R), as follows:

$R=0.10 \times\left[\left(1-\exp ^{-50 P D}\right) /\left(1-\exp ^{-50}\right)\right]+0.20 \times\left[1-\left(1-\exp ^{-50 P D}\right) /\left(1-\exp ^{-50}\right]\right.$

The specification in equation (1) contradicts studies that show that correlations are highest for the lowest quality (high PD) firms. That is, this specification is not supported by several academic studies cited earlier [e.g., Crouhy, Galai and Mark (2001), Zhou (2001) and Barnhill and Maxwell (1999)], but is supported by Das, Freed, Gang and Kapadia (2001).

Another criticism of the November 2001 proposed modifications of the Internal Ratings-Based Foundation Approach is that it understates the attainable level of default correlation by limiting it to an upper bound of $20 \%$. Gersbach and Wehrspohn (2001) suggest correlations that start around $25 \%$ for relatively unconcentrated portfolios up to $35 \%$ for concentrated portfolios. They propose a "lean IRB model" that is considerably simpler than the Internal Ratings-Based models, but still incorporates multiple systematic risk factors. This simplified IRB model would reduce the procyclicality of strict capital 
adequacy rules by smoothing one year PD rates over the business cycle. Similarly, Estrella (2001) proposes calibration of the VaR-based minimum capital requirement to the optimal capital during an economic downturn, rather than to an unconditional average across the business cycle. Alternatively, Gersbach and Wehrspohn (2001) and Purhonen (2002) propose explicit reductions in capital requirements during recessions to limit the procyclicality inherent in the New Capital Accord proposed by the BIS.

All BIS proposals aggregate regulatory capital simply by summing up the capital requirements for each asset individually. Gordy (2001) shows that this additivity assumption is correct only if the portfolio consists of an infinite number of atomistically small assets or if there is only a single systematic risk factor that drives all correlations in the model. BIS II proposals recognize that these conditions are not likely to hold in practice and therefore imposes a granularity adjustment that is a function of PD. Thus, if there is procyclicality in $\mathrm{PD}$, there will be procyclicality in the granularity adjustment. Pykhtin and Dev (2002) obtain an analytical solution for the granularity adjustment that is a function of the systematic risk factor in both PD and LGD.

In one of the few studies using international data, Purhonen (2002) finds evidence of considerable procyclicality in the Internal Ratings-Based (IRB) Foundation Approach to the New Capital Accords. Using KMV empirical EDFs as a measure of internal ratings, he examines minimum capital requirements over the period November 1996 June 2001 using both the January 2001 and November 2001 IRB calibrations. He finds considerable cyclical effects across all regional portfolios: US, EU, Asia-Pacific and Latin America. In particular, during the summer of 1998, during the Russian debt and Long Term Capital Management crises, the US banking system would have needed either 
significant infusions of capital or would have had to significantly reduce lending and sell assets, thereby exacerbating the cyclical downturn. Similar procyclical patterns were found for the EU and Latin American portfolios during the summer of 1998. In contrast, the Asian portfolio experienced considerable increases in credit risk exposure in late 1996, then again during the second half of 1998, and again during 2001. Thus, the increased capital requirements implied by the procyclical IRB could have exacerbated the Japanese economic crisis.

Concern about excessive procyclicality in the New Capital Accord is misplaced according to Jordan, Peek and Rosengren (2002). They find evidence of procyclical changes in capital requirements even in current regulations. That is, even in today's less risk sensitive environment, banks often experience declines (increases) in regulatory capital requirements during economic upturns (downturns), thereby exacerbating cyclical swings as capital-constrained banks cut down on lending during recessions and capitalrich banks increase lending during expansions. The current regulatory mechanism for these fluctuations is through mandated changes in provisioning for loan loss reserves. Rather than the automatic and continuous credit risk capital adjustment envisioned in the New Capital Accord, current credit risk adjustments to loan loss reserves often occur at discrete intervals, most often after a bank examination takes place. That is, Jordan, Peek and Rosengren (2002) document abrupt losses of bank capital during recessions that occur around the time of bank examinations. ${ }^{2}$ For example, during the 1990 recession, banks experienced declines in their capital ratios of over $4 \%$ within a one year period.

\footnotetext{
${ }^{30}$ Within the Asian portfolio, Japan accounted for $47 \%$ of the companies and $75 \%$ of the debt outstanding as of October 2001.

${ }^{31}$ Chiuri, Ferri and Majnoni (2002) find evidence of significant contractions in credit supply in emerging economies when regulatory capital requirements are more strictly enforced, although Saunders (2002) argues that risk-shifting could actually induce increases in the supply of credit.
} 
Thus, greater credit risk sensitivity in the proposed new capital requirements may not change the inherent procyclicality in bank capital regulations, but merely the timing of the realization of the procyclical effects. ${ }^{2}$ This point of view is supported by proponents of the contention that the cause of the 1990-1991 credit crunch and recession can be attributed to increased capital requirements under the original BIS Basel Capital Accord.

\section{Cyclical Effects on Loss Given Default (LGD)}

Anecdotal evidence suggests that systemic factors affect LGD as well as PD. 4 Altman and Kishore (1996) find that recovery rates are time-varying. Altman (1989) finds significant correlations between recovery rates and external credit ratings just prior to default. Dalianes (1999) refers to empirical evidence that recovery rates fluctuate over time and are negatively correlated with short term default risk-free interest rates because increases in interest rates (usually consistent with economic downturns) generally depress asset prices, thereby reducing recovery rates and increasing LGD. Gupton, Gates, and Carty (2000) and Crouhy, Galai and Mark (2000) find LGD variability around a mean value that is consistent with cyclical effects. Machlachlan (1999) finds that credit spreads are highest and therefore bond prices lowest during low points in the business cycle. This suggests a negative correlation between LGD and macroeconomic conditions because

\footnotetext{
${ }^{32}$ Estrella (2001) finds that optimal capital levels lag credit risk exposure (as measured by VaR) by about one quarter of a business cycle. Using data on US banks for 1984-1999, he finds procyclical patterns in external capital levels.

${ }^{33}$ Proponents of this view include Bernanke and Lown (1991), Hancock and Wilcox (1993, 1995), Berger and Udell (1994), Peek and Rosengren (1995), and Lown and Peristiani (1996). In contrast, opponents [such as Sharpe (1996)] argue that observed decreases in lending during capital-constrained downturns in economic activity may be the result of reduced loan demand rather than limitations in credit supply. ${ }^{34}$ However, Houweling and Vorst (2001) use a reduced form model to show that default swap prices are insensitive to the assumption of recovery values, although they do find a positive correlation between recovery rates and $\mathrm{PD}$.
} 
bond prices for distressed debt can be viewed as a lower bound on recovery amounts. Bangia, Diebold, and Schuermann (2000) use NBER designations of contractions and expansions to find that economic capital is $30 \%$ higher in a contraction year than in an expansion year, suggesting that loss rates (that is, PD x LGD) are procyclical.

\section{INSERT TABLE 9 AROUND HERE}

Table 9 shows some anecdotal evidence regarding the secular performance of LGD taken from Altman and Brady (2001). Weighted average recovery rates for all securities are lowest (below 30\%) in the recession years 1990 and 2000. 5 In all other years, recovery rates exceed $30 \%$. However, as in the case of PD, it is unclear whether these results indicate that the higher LGD during a recession is only a bad realization on a fixed loss distribution (i.e., point A on loss distribution 1 in Figure 1) or represents an actual shift in ex ante LGD (i.e., point A on loss distribution 2 in Figure 1).

Unfortunately, there has not been a lot of research into this question. In the following sections, we discuss the models that attempt to measure the cyclical effects on the ex ante expected loss given default.

Virtually no research has investigated the impact of structural factors into LGD procyclicality. For example, bankruptcy rules differ across countries and across time periods. During periods of economic crisis, bankruptcy rules are often leniently applied, as in Japan during the past decade. Moreover, as lenders prove more amenable to renegotiation during recessions, PD may decrease (since insolvent firms are allowed

\footnotetext{
${ }^{35}$ Weighted average recovery rates are computed using closing bond prices on or as close to the default date as possible, weighted by the market value of defaulting debt issues for all publicly traded corporate bonds. Ed Altman administers a bond database consisting of about 1,000 bonds for which reliable quotes are available.
} 
forbearance in order to avoid default), but recovery rates also may decrease. This results in procyclical increases in LGD during bad economic times.

The stringency of bankruptcy rules differs dramatically across countries. In the US, management is granted an exclusivity period immediately upon entering Chapter 11 during which the management cannot be removed (unless the courts find evidence of fraudulent behavior). During this period (which may last as long as nine months), the managers have a choice - they can either undertake activities to increase firm value or they can pursue their own self-interest and allow firm value to deteriorate further. To the extent that management concern about future employment prospects and personal reputation, as well as short term consumption of perquisites, outweighs the manager's long term interest in the distressed firm, the end of the exclusivity period may find the firm's creditors with substantially impaired assets, thereby reducing recovery rates and increasing LGD. To the extent that procyclicality affects the likelihood of bankruptcy, then the legal and regulatory environment governing bankruptcy administration is relevant for credit risk assessment. To our knowledge, this has not been incorporated into either academic or proprietary models.

\subsection{Academic Models}

Most academic and proprietary models make the simplifying assumption that recovery rates are exogenously determined. Indeed, the earliest models assumed a LGD that was a fixed, known fraction of the debt value. This was a critical assumption for reduced form models that enabled them to disentangle the PD from the LGD in the observed credit spread. Second generation credit risk measurement models have just begun to address the cyclicality in LGD. 


\subsubsection{Structural Models of Cyclical Effects on LGD}

Structural models evaluate the PD as the likelihood that the market value of assets will fall to the default point (the debt value). Once default occurs, debtholders receive the market value of the firm's assets. Thus, if there is a cyclical component built into asset valuations, then it also impacts recovery rates. Despite this, most structural models [e.g., Kim, Ramaswamy and Sundaresan (1993), Hull and White (1995), and Longstaff and Schwartz (1995)] assume that LGD is exogenously determined. An exception to this is a series of papers by Frye. Frye (2000b) uses a bond database to find evidence of cyclical recovery rates. Table 10 shows that LGD increases dramatically for all levels of credit risk in depressed states of the world, as compared to normal macroeconomic conditions. Thus, collateral values fluctuate with economic conditions. Indeed, recovery rates may decline $20-25 \%$ in severe economic downturns. Thus, Frye (2000b) cautions that "collateral should not lead to complacency" on the part of lenders. Collateral values are particularly sensitive to economic downturns for three reasons: (1) The direct effect of systematic risk exposure; (2) An indirect effect if distressed obligors cut back on asset/collateral maintenance and control; and (3) An indirect effect if distressed lenders dump assets/collateral in fire sale liquidations.

\section{INSERT TABLE 10 AROUND HERE}

Frye (2000a) models collateral values as a function of both idiosyncratic and systematic risk factors, finding a considerable impact of cyclical factors on expected losses. Frye (2000b) estimates that the correlation between asset values and the systematic risk factor (for a US bond database over the period 1983-1997) is $23 \%$ and that the correlation between collateral values and the systematic risk factor is almost the

\footnotetext{
${ }^{36}$ Pulvino (1998) finds evidence of asset fire sales in the commercial aircraft market.
} 
same: $17 \%$ To illustrate the impact of cyclical factors on both PD and LGD, consider that the unconditional expected loss (EL) is defined to be PD x LGD. Using an example from Frye (2000a), suppose that $\mathrm{PD}=5 \%$ and expected $\mathrm{LGD}=10 \%$; then the unconditional EL is $0.5 \%$. If only the PD is conditioned on an economic downturn, such that $\mathrm{PD}=45.4 \%$ in a recession, then the EL increases to $4.5 \%$. However, if both the PD and LGD are conditioned on the economic downturn such that conditional LGD=26.1\% [from Frye (2000a)], then the conditional EL $=45.4 \%$ x $26.1 \%=11.8 \%$ shows a considerable increase over the unconditional EL.

Jokivuolle and Peura (2000) model the recovery rate as a function of the PD and show that the expected LGD is a decreasing function of the growth rate in the value of collateral, an increasing function of the volatility of the collateral value, and an increasing function of the correlation between the collateral value and the value of the borrower firm's total assets. Moreover, the expected LGD is a decreasing function of the default probability of the borrower, given that the correlation between the collateral and the firm values is positive. This counterintuitive result obtains because of the use of an options theoretic structural model to depict default. That is, low PD firms must experience abnormally large negative shocks to asset values to enter the default region and therefore the value of their collateral is quite impaired. In contrast, high PD firms (with a low distance-to-default) are thrown into default by only slight declines in asset values. Thus, the recovery rates of low credit quality firms tend to be higher than recovery rates in high credit quality firms in the Jokivuolle and Peura (2000) simulations.

\footnotetext{
${ }^{37}$ Frye (2000b) also estimates that the standard deviation of collateral values is $32 \%$, suggesting that collateral values are very volatile. Conditional on a realization of the systematic risk factor, PD and LGD are assumed to be independent. Thus, for a given state of the economy, the conditional EL equals product of the conditional PD and the conditional LGD.
} 
Erlenmaier and Gersbach (2001) consider endogenous recovery rates that are a fixed fraction of asset values. The impact of endogenous LGD is to increase default correlations as compared to the exogenous case. ${ }^{8}$ Moreover, the relationship between PD levels and default correlations is exacerbated when LGD is endogenously determined by asset values. However, this result assumes that the cyclical effect is constant over time. If instead there are regime shifts that affect the firm's exposure to systematic and idiosyncratic risk factors, then the default correlation function will shift over time. Indeed, extreme outcomes (i.e., boom or bust) may result in greater default correlations because information is revealed about the underlying regime state. Thus, if PD and LGD both increase in economic downturns and decrease in economic upturns, then the cyclical effect (as measured by both default correlations and LGD correlations) will be more pronounced.

\subsubsection{Reduced Form Models of Cyclical Effects on LGD}

Reduced form models estimate the default intensity function using observed credit spreads on risky debt. The credit spread is defined as PD x LGD. Thus, reduced form models must find some way to disentangle the PD from the LGD in each observation of the credit spread. Many of the earlier reduced form models focused on modeling the default intensity, PD, in order to disentangle these two components of the credit spread. Their simplifying assumptions that the LGD was either constant or proportion to bond value were counterfactual. As we have seen, observed recovery rates are volatile and appear to have a cyclical component. Moreover, the default intensity also fluctuates with the business cycle and systemic risk conditions.

\footnotetext{
${ }^{38}$ This is true whatever the sign of the correlation coefficient because loan repayments provide full information about realized returns when recovery rates are endogenous, thereby increasing default correlations as compared to the exogenous LGD case.
} 
Das and Tufano (1995) allow a proportional LGD to vary over time, but maintain the assumption of independence between LGD and PD. Duffie and Singleton (1999) allow for (economic) state-dependence of both LGD and PD, as well as interdependence between LGD and PD; however, they assume independence between firm asset value and the LGD and PD processes, an assumption that does not hold if, for example, the debt obligation is a large part of the issuer's capital structure.

The pure recovery model of Unal, Madan and Guntay (2001) decomposes the difference between the price of senior versus junior debt in order to obtain a measure of recovery rates on senior debt relative to junior debt that is independent of default probabilities. The recovery rate is conditioned on the business cycle (measured using macroeconomic factors) and firm specific information. Table 11 shows that the estimated mean recovery rates (1-LGD) for the 11 companies in the sample ${ }^{69}$ are extremely volatile both across time and cross-sectionally, thereby casting doubt on the assumption of a constant LGD rate.

\section{INSERT TABLE 11 AROUND HERE}

\subsection{Proprietary Models}

Most proprietary models have not incorporated cyclical effects into their modeling of LGD. Many proprietary models (KMV, CreditMetrics, Credit Risk Plus) make simple distributional assumptions (e.g., the beta distribution) about LGD values that do not contain a systematic risk component. An exception to this is Kamakura Risk Manager. Kamakura uses equity prices to obtain a liquidation value that can be viewed

\footnotetext{
${ }^{39}$ There would not have been enough observations for the Unal, Madan and Guntay (2001) study if the sample were limited to zero coupon, non-callable debt as is usually done in reduced form models; therefore, junior and senior debt issues were matched by choosing the closest possible duration and coupon rates. There were only 11 companies with enough data to fully estimate the model.
} 
as the LGD. That is, the market value of equity can be viewed as a lower bound on LGD in the sense that recovery rates on debt must at least equal the market value of equity. The recovery rate is calculated as one minus the market value of equity to assets ratio (i.e., the debt ratio in market value terms) times the face value of the debt. The seniority order in priority of claims on the firm's assets seems to suggest that if the market value of equity exceeds zero, then all creditors are expected to receive full payment on their claims; thereby, implying that $\mathrm{LGD}=0$. However, in more than $75 \%$ of the cases of bankrupt firms, reorganization entails deviations from absolute priority. Because of US bankruptcy laws which assign voting power to blocks of claimants on a pro rata basis, even junior claimants (such as common stockholders) may have the power to block a reorganization plan and thereby demand a share of the payout, even if senior claimants are not paid in full. Thus, the market value of equity can be viewed as a lower bound on the payout to senior claimants such as debtholders. Since equity prices fluctuate with cyclical conditions, the Kamakura estimate of LGD is therefore cyclically adjusted.

\section{The Correlation Between PD and LGD}

We have seen that many models of credit risk measurement incorporate cyclical factors into their estimation of PD, but not LGD. The sophistication of modeling deteriorates even further when considering feedback effects between PD and LGD. That is, evidence suggests the existence of cyclical components in both PD and LGD. If both PD and LGD are correlated to the same systematic risk factors, then they should be correlated with each other. This section surveys academic studies that consider the joint cyclicality of PD and LGD. There is no section on proprietary models because there are 
no models that we are aware of that explicitly consider the correlation between PD and

LGD.

\subsection{Academic Models}

In Frye's (2000a,b) structural model, collateral and asset values are modeled using a single index based on a systematic and an idiosyncratic risk factor. Correlations between PD and LGD then are obtained by the joint factor loadings on the systematic risk factor for both the asset and collateral valuation functions. Thus, correlations between PD and LGD result from the joint dependence of collateral and asset values on systematic risk factors. It is therefore not surprising that the correlation coefficients for both asset and collateral values with the systematic risk factor are estimated to be almost identical: $23 \%$ vs. $17 \%$. Conceptually, therefore, the correlation between PD and LGD emanates from the assumption that recovery rates are determined by the valuation of all assets, including the loan's collateral. Thus, the collateral valuation function is based on the single index asset valuation function.

Altman , Resti and Sironi (2002) exhaustively investigate the correlation between both ex post realized and simulated default rates and recovery rates. Using a US corporate bond database covering the period 1982-2000, they empirically estimate the relationship between PD and recovery rates. They find strong evidence of an inverse relationship such that recovery rates fall (rise) when PD increases (decreases). The explanation for this result stems from supply and demand considerations in the market for distressed debt. When default rates increase, for instance in cyclical downturns, there is likely to be more defaulted bonds available for sale on the distressed debt market. The

\footnotetext{
${ }^{40}$ Frye'a (2000a) model ignores a possible relationship between the asset idiosyncratic risk factor and collateral values or between the collateral idiosyncratic risk factor and asset values.
} 
demand for such below investment grade instruments is relatively inelastic since buyers are restricted to "vulture" funds and the few financial intermediaries that are permitted invest in this paper. ${ }^{-11}$ Thus, since supply increases during cyclical downturns whereas demand is relatively stable, the price of distressed debt declines, thereby reducing recovery values when defaults increase. Using parameter values consistent with the size of the market in 2001, Altman, Resti and Sironi (2002) estimate that recovery rates are $20 \%$ assuming an $8.5 \%$ default rate as compared to a recovery rate of $18 \%$ assuming a $10 \%$ default rate. ${ }^{ \pm 2}$ However, explicitly controlling for macroeconomic effects (using variables like GDP and changes in GDP) yields insignificant and inconsistent results in the Altman, Resti and Sironi (2002) model.

Despite the plausibility of an inverse relationship between PD and recovery rates, the question may be posed as to its empirical significance. For example, is the abovementioned decrease in recovery rate from $20 \%$ to $18 \%$ economically significant?

Altman, Resti and Sironi (2002) demonstrate the important implications of correlated PD and LGD in two ways: (1) Simulating three different recovery rate scenarios (only one of which assumes correlated PD and LGD) and examining the impact on credit risk measures; and (2) Simulating the impact of cyclical fluctuations on capital requirements as proposed under the New Basel Capital Accord's Internal Ratings-Based Foundations Approach. Both show the considerable impact of correlated PD and LGD.

\footnotetext{
${ }^{41}$ Altman (1991) attempted to measure the size of demand in this market for "alternative investments" and estimated that the vulture funds had at least $\$ 7$ billion under management in 1991. In contrast, the supply of distressed and defaulted public and private bonds (selling at a credit spread at least 1000 basis points over 10 year Treasury bond rates) was approximately $\$ 300$ billion during the 1990-1991 period. Given the ten to one disparity in size between the supply and demand sides of the market, Altman, Resti and Sironi. (2002) contend that even dramatic increases in demand would not be sufficient to absorb the increased supply during cyclical downturns.

${ }^{42}$ The actual recovery rate in 2001 was $25.5 \%$ and the default rate in 2001 was $9.8 \%$; see Altman and Arman (2002).
} 
The first simulation analysis performed by Altman, Resti and Sironi (2002) considers deterministic recovery rates (as in the basic model of Credit Risk Plus), stochastic yet uncorrelated LGD (as in CreditMetrics), and stochastic and correlated LGD. ${ }^{43}$ They find no significant differences in the VaR under the first two scenarios. However, Table 12 shows that consideration of correlated LGDs increase the estimates of VaR by as much as $30 \%$.

\section{INSERT TABLE 12 AROUND HERE}

To test the implications of correlated PD and LGD on bank capital requirements, Altman, Resti and Sironi (2002) compare the January 2001 proposals to the November 2001 proposals for the Internal Ratings-Based Foundation Approach. Two possible LGD scenarios are used: (1) a fixed 50\% LGD; and (2) LGDs fluctuate between 60\% in high default years and $40 \%$ in low default years. They find evidence of procyclical fluctuations in minimum capital requirements such that loan portfolios can grow during economic upturns and are forced to shrink during downturns. Moreover, consideration of correlated PD and LGD exacerbates these procyclical swings.

\section{Cyclical Effects on Exposure At Default (EAD)}

Credit risk measures depend on PD, LGD and exposure at default (EAD). Both regulatory and proprietary models typically define EAD to be the book value of assets less any netting due to credit risk mitigation factors. Similarly, academic models take

\footnotetext{
${ }^{43}$ Under their specification, LGDs increase up to $50 \%$ in economic downturns and go down to $10 \%$ in economic boom periods. That is, Altman, Resti and Sironi (2002) use a single index model in which the systematic and idiosyncratic risk factors each receive a 50\% weight. In contrast, the January 2001 Basel proposal assumes a 33-67\% systematic-idiosyncratic weighting scheme.

${ }^{44}$ Interestingly, the procyclical tendencies are the same in both the January 2001 and November 2001 calibrations of the Basel capital proposals. This is because the November 2001 risk weighting function is steeper than the January 2001 risk weight function in the interior "normal" credit quality classifications, although the Janaury 2001 risk weight function is more convex over all default specifications.
} 
exposures as given. However, there is anecdotal evidence of procyclicality in EAD, particularly for loan commitments. That is, the likelihood of commitment takedown and the extent of commitment usage increases during economic downturns when credit is tight and credit-constrained firms are experiencing liquidity crises. Table 13 reproduces the results of Asarnow and Marker (1995) showing the significant increase in takedown rates upon default. This effect is particularly strong for firms that had better credit ratings prior to default. Thus, if default is more sudden (and perhaps more likely to be triggered by downturns in macroeconomic activity), then the increase in the lender's EAD (through increased loan exposure as a result of increased commitment takedown) is more pronounced. More marginal firms are less likely to be permitted to take down large percentages of their loan commitments after default, perhaps because of the lender's invocation of the material adverse change clause that permits the lender to alter the terms of the commitment ex post. Thus, the procyclicality in EAD appears to be introduced mostly through high credit quality obligations.

\section{INSERT TABLE 13 AROUND HERE}

\subsection{Structural Models of Cyclical Effects on EAD}

Academic models have only peripherally investigated procyclicality in EAD. Mueller (2000) and Collin-Dufresne and Goldstein (2001) model leverage levels as a function of macroeconomic factors. That is, the level of indebtedness may increase at the low point of the business cycle, as in the anecdotal example that loan commitments are increasingly taken down by credit constrained firms. The procyclicality in leverage levels leads to increased EAD just at the time that PD increases. This procyclical effect exacerbates credit risk exposure. Moreover, Anderson and Sundaresan (2000) use 
economy-wide measures of asset volatility and profitability in order to compute a cyclical leverage ratio that results in increases (decreases) in EAD during macroeconomic downturns (upturns). Incorporating this cyclically adjusted leverage ratio improves the quality of model estimates of PD as compared to the Merton (1974) model.

Credit supply and demand is further linked by Hofmann (2001) by including property prices in a cointegration analysis. He finds that real GDP and real interest rates are not sufficient to explain the long run development of credit availability. However, including real property prices (measured as the weighted average of real residential and real commercial property prices) results in a model that links credit availability to GDP, property prices and interest rates. This model is procyclical and can generate financial bubbles based on inflated property prices. That is, increases in property prices increase lending and vice versa. Therefore, inflationary booms and deflationary busts are selfsustaining.

Saunders and Mei (1997) also find evidence of cyclicality in the supply of real estate loans. However, their findings can be interpreted as evidence of countercyclicality. They find that past trends in real estate returns drive the supply of credit for real estate purchases, such that lending increases (decreases) when past excess returns on real estate increases (decreases), although future expected returns are decreasing (increasing). This "trend chasing" behavior may actually insulate banks against procyclicality in EAD if property prices fall before recessions. That is, banks reduce (increase) their real estate lending exposure prior to the recession (expansion) because of the trend chasing cyclicality in lending that alternates between booms and slumps in real estate credit availability. However, if real estate price fluctuations lag macroeconomic 
fluctuations, then bank trend chasing behavior would instead exacerbate the procyclicality of EAD. Borio and Lowe (2002) propose the development of a signal of speculative excess that would be comprised of the credit/GDP gap, the real asset price gap, and the investment/GDP gap. If used to guide monetary and prudential policy, they contend that this early warning system could prevent the boom/bust cycles in credit markets.

The relationship between lending activity and macroeconomic conditions is also modeled by Lown and Morgan (2001) who find that bank lending standards display counter cyclical tendencies as evidenced in a credit cycle. Lown and Morgan (2001) show that fluctuations in commercial credit standards at banks lead to fluctuations in both the Fed Funds rate and in the level of commercial lending activity, which in turn lead to fluctuations in credit quality. Using Federal Reserve surveys, they find that all recessions since 1967 have been preceded by an increase in the percentage of loan officers reporting tightening credit standards for commercial and industrial loans or credit lines. Moreover, changes in the business failure rate account for about $10 \%$ of the change in credit standards. Thus, bank EADs may decline as lending standards are tightened before cyclical downturns, thereby providing a counter cyclical impact on bank credit risk exposure. Of course, Lown and Morgan's (2001) results apply only to the US. It is unclear whether the counter cyclical effects are generalizable to other countries. In particular, this effect might be more relevant in bank-dominated systems. However, it may not be applicable in countries such as Japan in which the banking system has been unable to efficiently perform the capital allocation process.

\footnotetext{
45 This suggests that central banks may set monetary policy by following property price fluctuations. Goodhart (1995) suggests that financial cycles of the late 1980s and early 1990s could have been avoided if central banks had targeted property prices in the conduct of their monetary policies.
} 
Cavallo and Majnoni (2001) and Borio, Furfine and Lowe (2001) also model potential counter cyclical effects. They argue that if loan loss reserves are set to equal expected losses, in a forward-looking predictive manner, rather than equal to ex post realized losses, then the procyclical tendencies of banking can be mitigated somewhat. That is, as economic conditions are forecast to deteriorate, the bank would be required to reserve higher levels against the higher loan losses expected to occur because of the cyclical sensitivity of both PD and LGD, thereby reducing lending activity (EAD) at capital constrained banks in preparation for a cyclical downturn.

\subsection{Reduced Form Models of Cyclical Effects on EAD}

Chang and Sundaresan (1999) examine an equilibrium model of asset pricing in which asset prices, the default risk-free term structure and the default premiums are all determined endogenously. Borrowers optimally default when the cost of default (forfeiture of assets) is lower than the savings from repudiated debt service. As economic conditions deteriorate (and the value of assets falls), the PD increases, causing investors to become more risk averse. This leads to the "flight to quality" observed in the low point of the business cycle. Since cyclical variations lead to fluctuations in the default risk-free rate of interest in the Chang and Sundaresan (1999) model, then changes in PD are inversely related to changes in default risk-free interest rates. That is, as PD increases, investors seek default risk-free investments, thereby bidding down the yield and increasing EAD. Thus, as the value of assets declines (in a cyclical downturn), the default premium increases, default risk-free interest rates decline and the default risk-free term structure becomes steeper. The endogenous correlation structure between PD and 
default risk-free interest rates is driven, in part, by fluctuations in EAD caused by the procyclical flight to quality.

The results of Chang and Sundaresan (1999) are consistent with several reduced form models that incorporate the correlation between default risk-free interest rates and default risk. Longstaff and Schwartz (1995) utilize a two factor model that specifies a negative relationship between the stochastic processes determining credit spreads and default-free interest rates. Duffee (1998) finds that changes in credit spreads are negatively related to changes in risk-free interest rates for lower credit quality bonds. However, using a structural model, Collin-Dufresne, Goldstein and Martin (2001) find little correlation between macroeconomic variables and changes in credit spreads. That is, they find evidence of a common factor driving credit spreads, but cannot relate that common factor to any of the standard macroeconomic variables that are used to measure liquidity, changes in the business climate, changes in market volatility, changes in the level of interest rates and the slope of the yield curve, leverage changes and other firmspecific variables. Thus, they find evidence of the significant cross-correlations across credit spread changes that would be consistent with procyclicality, but cannot find any direct evidence of macroeconomic and systemic risk effects. Although they use two separate databases on US bond prices, they conclude that their results may be due to market imperfections (such as transaction costs and illiquidity) in the US bond market that may inject noise into bond prices. However, they call for more research examining the interaction between market risk and credit risk as a possible explanation for this mysterious common factor affecting credit spreads. 


\subsection{Integrating Credit Risk and Market Risk}

The integration of credit risk and other components of risk exposure, such as interest rate risk and market risk, is still in its infancy. However, ignoring the correlations between interest rate risk and credit risk may result in faulty estimates of both risk exposures. Barnhill and Gleason (2001) consider the correlation of credit and interest rate risk. They show that correlations across risk exposures can cause an increase in failure probability for a bank with a positive duration gap. That is, increases in credit risk exposure are accompanied by increases in interest rate risk exposure. Bhansali and Wise (2001) forecast future correlation matrices using underlying risk factors such as interest rate risk (duration), a mortgage spread risk factor and a corporate spread risk factor. They show that the loan portfolio's duration can be shortened by almost $50 \%$ as a result of the increased credit risk associated with shifting from a normal to a stressed economic scenario. Moreover, Bhansali and Wise (2001) show that crisis economic conditions may cause risk factors to move beyond their historical levels, thereby underscoring the importance of using forecast measures of correlations in credit risk estimates, rather than simply taking historical averages. In contrast, however, Allen, Jagtiani and Landskroner (1996) find a negative correlation between credit risk exposure (as measured in BIS I) and interest rate risk exposure for banks engaged in regulatory capital arbitrage.

\section{Conclusion}

In this paper, we survey the literature on cyclical effects on PD, LGD and EAD. Although systematic risk factors have been incorporated into both academic and 
proprietary models of PD, the same is not true for LGD and EAD. Moreover, systematic correlation effects between PD and LGD, PD and EAD, and LGD and EAD have been virtually ignored in the literature. Clearly, a great deal of work needs to be done in these areas before regulators will be convinced that bank internal models can accurately measure credit risk exposures, especially in recessions. 


\section{Table 1}

\section{The Relationship Between PD} and Macroeconomic Conditions

\begin{tabular}{|c|c|c|}
\hline Year & Default Rate & Default Loss \\
\hline 3 Q 2001 & $6.92 \%$ & $5.29 \%$ \\
\hline 2000 & 5.06 & 3.94 \\
\hline 1999 & 4.15 & 3.21 \\
\hline 1998 & 1.60 & 1.10 \\
\hline 1997 & 1.25 & 0.65 \\
\hline 1996 & 1.23 & 0.65 \\
\hline 1995 & 1.90 & 1.24 \\
\hline 1994 & 1.45 & 0.96 \\
\hline 1993 & 1.11 & 0.56 \\
\hline 1992 & 3.40 & 1.91 \\
\hline 1991 & 10.27 & 7.16 \\
\hline 1990 & 10.14 & 8.42 \\
\hline
\end{tabular}

Source: Altman (2002). 


\section{Table 2}

\section{Systematic Risk (Beta) by Bond Rating Category \\ Barnhill and Maxwell (1999) - Table VI}

\begin{tabular}{|c|c|c|}
\hline Rating Category & $\begin{array}{c}\text { Mean Beta (1993-1998) } \\
\text { for Low Volatility Firms }\end{array}$ & $\begin{array}{c}\text { Mean Beta (1993-1998) } \\
\text { for High Volatility Firms }\end{array}$ \\
\hline $\mathrm{Aaa}$ & 0.679 & 0.682 \\
\hline $\mathrm{Aa}$ & 0.649 & 0.757 \\
\hline $\mathrm{A}$ & 0.699 & 0.864 \\
\hline $\mathrm{Baa}$ & 0.864 & 0.994 \\
\hline $\mathrm{Ba}$ & 1.019 & 1.131 \\
\hline $\mathrm{B}$ & 1.314 & 1.314 \\
\hline $\mathrm{Caa}$ & 1.301 & 1.301 \\
\hline
\end{tabular}

Note: Low (high) volatility firms were defined to be those in the lower third (remaining two thirds) of total equity return volatility. 
Table 3

Default Correlations and Increasing PD

Gersbach and Lipponer (2000) - Table 1

\begin{tabular}{|c|c|c|}
\hline Default Probability & $\begin{array}{c}\text { Default Correlation if } \\
\text { Asset Correlation = 40\% }\end{array}$ & $\begin{array}{c}\text { Default Correlation if } \\
\text { Asset Correlation = 80\% }\end{array}$ \\
\hline $1 \%$ & 0.08 & 0.37 \\
\hline $5 \%$ & 0.14 & 0.47 \\
\hline $10 \%$ & 0.18 & 0.51 \\
\hline $15 \%$ & 0.21 & 0.54 \\
\hline $20 \%$ & 0.22 & 0.56 \\
\hline $25 \%$ & 0.24 & 0.57 \\
\hline $30 \%$ & 0.25 & 0.58 \\
\hline $35 \%$ & 0.25 & 0.58 \\
\hline $40 \%$ & 0.26 & 0.58 \\
\hline $45 \%$ & 0.26 & 0.59 \\
\hline $50 \%$ & 0.26 & 0.59 \\
\hline
\end{tabular}


Table 4

\section{Term Structure in Default Correlations Zhou (2001), Table 8}

\begin{tabular}{|c|c|c|c|c|c|c|}
\hline \multirow{2}{*}{$\begin{array}{c}\text { Credit } \\
\text { Quality }\end{array}$} & \multicolumn{7}{|c|}{ Investment Time Horizon } \\
\cline { 2 - 7 } High grade & $0.0 \%$ & $0.02 \%$ & $0.23 \%$ & $0.80 \%$ & $1.72 \%$ & $7.93 \%$ \\
\hline Low grade & $4.29 \%$ & $12.2 \%$ & $16.8 \%$ & $19.5 \%$ & $21.1 \%$ & $24.0 \%$ \\
\hline
\end{tabular}

Table 5

Correlations Across Risk Factors Geyer, Kossmeier and Pichler (2001) Table 2

\begin{tabular}{|c|c|c|c|c|c|c|}
\hline & $\frac{\text { Correlations }}{\text { Austria }}$ & Belgium & $\frac{\text { Country }}{\text { Italy }}$ & $\begin{array}{c}\text { Factors: } \\
\text { Netherlands }\end{array}$ & $\begin{array}{c}\text { Global } \\
\text { Factor } \\
\text { Loadings }\end{array}$ & $\begin{array}{c}\text { Country } \\
\text { Factor } \\
\text { Loadings }\end{array}$ \\
\hline Austria & & & & & 0.371 & 0.272 \\
\hline Belgium & -0.83 & & & & 0.462 & 0.181 \\
\hline Italy & -0.04 & 0.04 & & & 0.434 & 0.198 \\
\hline Netherlands & 0.68 & -0.77 & -0.10 & & 0.305 & 0.168 \\
\hline Spain & -0.80 & 0.78 & 0.32 & -0.78 & 0.488 & 0.253 \\
\hline
\end{tabular}

Notes: Factor loadings are average squared loadings with the respective risk factor. All other are correlations. The correlation between the global factor and each of the country factors is zero by construction. 


\section{Table 6}

\section{Correlations under Time-Varying Default Probabilities}

Das, Freed, Geng, Kapadia (2001) - Table 5

\begin{tabular}{|l|c|c|c|c|}
\hline \multicolumn{1}{|c|}{ Group } & $\begin{array}{c}\mathbf{1 / 8 7 - 4 / 9 0} \\
\text { Time Period }\end{array}$ & $\begin{array}{c}\mathbf{5 / 9 0 - 1 2 / 9 3} \\
\text { Time Period }\end{array}$ & $\begin{array}{c}\mathbf{1 / 9 4}-\mathbf{4 / 9 7} \\
\text { Time Period }\end{array}$ & $\begin{array}{c}\mathbf{5 / 9 7 - 1 0 / 0 0} \\
\text { Time Period }\end{array}$ \\
\hline High Credit & 0.34 & 0.11 & 0.03 & 0.13 \\
Quality & {$[0.37]$} & {$[0.10]$} & {$[0.01]$} & {$[0.11]$} \\
\hline Medium Credit & 0.25 & 0.13 & 0.04 & 0.10 \\
Quality & {$[0.23]$} & {$[0.10]$} & {$[0.02]$} & {$[0.08]$} \\
\hline Low Credit & 0.19 & 0.09 & 0.03 & 0.10 \\
Quality & {$[0.16]$} & {$[0.07]$} & {$[0.02]$} & {$[0.08]$} \\
\hline
\end{tabular}

Notes: The subperiods were endogenously determined using a switching of regression regimes model. The means [median] of pairwise correlations between firms belonging to each group are presented in the table.

\section{Table 7}

\section{Simulated Systematic Risk Premiums}

\section{Belkin, Suchower and Forest (1998) Table 3}

\begin{tabular}{|c|c|c|c|c|c|c|}
\hline Aaa & Aa & A & Baa & Ba & B & Caa \\
\hline $4.6 \mathrm{bp}$ & $8.5 \mathrm{bp}$ & $17.5 \mathrm{bp}$ & $35.9 \mathrm{bp}$ & $181.5 \mathrm{bp}$ & $317.5 \mathrm{bp}$ & $839.0 \mathrm{bp}$ \\
\hline
\end{tabular}

Notes: The systematic risk premium is estimated for the par spreads on a simulated loan portfolio of 10,000 loans with the same external credit rating and with an assumed pairwise correlation coefficient of $25 \%$. 
Table 8

Conditional Transition Matrices - CreditPortfolio View

Saunders and Allen (2002) Appendix 7.1

Unconditional Transition Matrix:
A
$\mathrm{B}$
$\mathrm{C}$
D
$\mathrm{C}$
.01
.04
.80
.15

Conditional Transition Matrix:

$\begin{array}{llll}\text { A } & \text { B } & \text { C } & \text { D }\end{array}$

$\begin{array}{lllll}\mathrm{C} & .0124 & .034 & .7796 & .174\end{array}$

Table 9

The Relationship Between Recovery Rates and Macroeconomic Conditions Altman with Brady (2001)

\begin{tabular}{|c|c|c|c|c|}
\hline Year & Senior Secured & Senior Unsec. & Subordinated & All Securities \\
\hline 3Q2001 & $40.95 \%$ & $33.19 \%$ & $0 \%$ & $28.02 \%$ \\
\hline 2000 & 39.58 & 25.40 & 26.62 & 25.83 \\
\hline 1999 & 26.90 & 42.54 & 13.88 & 31.14 \\
\hline 1998 & 70.38 & 39.57 & 0 & 37.27 \\
\hline 1997 & 74.90 & 70.94 & 60.00 & 53.89 \\
\hline 1996 & 59.08 & 50.11 & 44.23 & 51.91 \\
\hline 1995 & 44.64 & 50.50 & 20.00 & 41.77 \\
\hline 1994 & 48.66 & 51.14 & 37.04 & 39.44 \\
\hline 1993 & 55.75 & 33.38 & 28.38 & 38.83 \\
\hline 1992 & 59.85 & 35.61 & 49.13 & 50.03 \\
\hline 1991 & 44.12 & 55.84 & 24.30 & 40.67 \\
\hline 1990 & 32.18 & 29.02 & 18.83 & 24.66 \\
\hline
\end{tabular}




\section{Table 10}

Frye (2000b)

\begin{tabular}{|c|c|c|c|c|c|}
\hline Paramter Values & $\mathbf{( 1 )}$ & $\mathbf{( 2 )}$ & $\mathbf{( 3 )}$ & $\mathbf{( 4 )}$ & $\mathbf{( 5 )}$ \\
\hline $\begin{array}{c}\text { Standard deviation } \\
\text { of recovery rate }\end{array}$ & 0.32 & 0.32 & 0.32 & 0.25 & 0.25 \\
\hline PD & $1.99 \%$ & $2.00 \%$ & $0.20 \%$ & $2.00 \%$ & $0.20 \%$ \\
\hline Expected LGD & $59.1 \%$ & $30.7 \%$ & $30.7 \%$ & $30.7 \%$ & $30.7 \%$ \\
\hline Normal state PD & $1.8 \%$ & $1.7 \%$ & $0.2 \%$ & $1.7 \%$ & $0.2 \%$ \\
\hline $\begin{array}{c}\text { Normal state LGD } \\
\text { Depressed state PD }\end{array}$ & $55 \%$ & $28 \%$ & $27 \%$ & $28 \%$ & $28 \%$ \\
\hline $\begin{array}{c}\text { Depressed state } \\
\text { LGD }\end{array}$ & $80 \%$ & $14.8 \%$ & $2.9 \%$ & $14.8 \%$ & $2.9 \%$ \\
\hline $\begin{array}{c}\text { Normal state } \\
\text { Expected Loss }\end{array}$ & $\mathbf{0 . 9 9 \%}$ & $\mathbf{0 . 4 8 \%}$ & $\mathbf{0 . 0 5 \%}$ & $\mathbf{0 . 4 8 \%}$ & $\mathbf{0 . 0 6 \%}$ \\
\hline $\begin{array}{c}\text { Distressed state } \\
\text { Expected Loss }\end{array}$ & $\mathbf{8 . 3 2 \%}$ & $\mathbf{7 . 7 0 \%}$ & $\mathbf{1 . 4 8 \%}$ & $\mathbf{6 . 9 6 \%}$ & $\mathbf{1 . 3 6 \%}$ \\
\hline
\end{tabular}

Note: For all model specifications, the systematic risk beta for assets (collateral) is 0.23 (0.17). 


\section{Table 11 \\ Unal, Madan and Guntay (2001)}

Table 5.1

Estimating Recovery Rates (1-LGD) Using a

Reduced Form Model

\begin{tabular}{|l|c|c|c|c|}
\hline Company & $\begin{array}{c}\text { Estimated } \\
\text { Mean } \\
\text { Recovery } \\
\text { Rate }\end{array}$ & $\begin{array}{c}\text { Volatility of } \\
\text { Recovery } \\
\text { Rate } \\
\boldsymbol{\sigma}\end{array}$ & $\begin{array}{c}\text { Industry } \\
\text { Average }\end{array}$ & $\begin{array}{c}\text { Root Mean } \\
\text { Squared } \\
\text { Error }\end{array}$ \\
\hline AMC & 52.2 & 2.969 & 37.1 & 0.042 \\
\hline American Medical & 12.5 & 0.500 & 26.5 & 0.037 \\
\hline Coastal Corp. & 63.3 & 0.010 & 70.5 & 0.100 \\
\hline Envirotest Systems & 34.3 & 0.118 & 46.2 & 0.075 \\
\hline Flagstar & 12.7 & 0.713 & 33.2 & 0.045 \\
\hline Revlon & 40.5 & 0.447 & 62.7 & 0.083 \\
\hline Sequa Corp. & 59.2 & 0.081 & 38.4 & 0.073 \\
\hline Stone Container & 9.6 & 0.113 & 29.8 & 0.082 \\
\hline Sweetheart Cup & 56.7 & 0.124 & 62.7 & 0.064 \\
\hline Valassis Insterts & 19.1 & 0.010 & 46.2 & 0.086 \\
\hline Del Webb Corp. & 39.3 & 1.163 & 35.3 & 0.026 \\
\hline Source: Unat,
\end{tabular}

Source: Unal, et. al. (2001). Industry averages are obtained from Altman and Kishore (1996). 


\section{Table 12}

\section{Simulations of LGD Scenarios on Credit Risk Measures}

Altman, Resti and Sironi (2002), Table 2

\begin{tabular}{|c|c|c|c|c|}
\hline & $\begin{array}{c}\text { Deterministic } \\
\text { LGD }\end{array}$ & $\begin{array}{c}\text { Stochastic, but } \\
\text { uncorrelated } \\
\text { LGD }\end{array}$ & $\begin{array}{c}\text { Stochastic } \\
\text { LGD partially } \\
\text { correlated } \\
\text { with PD } \\
\mathbf{( 3 )}\end{array}$ & $\begin{array}{c}\text { Comparison } \\
\text { Betw. Col. (1) } \\
\text { and Col. (3) } \\
\mathbf{( 3 )}-\mathbf{( 1 )}\end{array}$ \\
\hline Expected Loss & $\mathbf{( 1 )}$ & $\mathbf{( 2 )}$ & 598 & $29.4 \%$ \\
\hline Standard Error & 983 & 458 & 1,272 & $29.5 \%$ \\
\hline $95 \% \mathrm{VaR}$ & 1,899 & 978 & 2,449 & $28.9 \%$ \\
\hline $99 \% \mathrm{VaR}$ & 3,835 & 3,851 & 4,972 & $29.6 \%$ \\
\hline $99.5 \% \mathrm{VaR}$ & 3,591 & 3,579 & 4,653 & $29.6 \%$ \\
\hline $99.9 \% \mathrm{VaR}$ & 3,738 & 3,774 & 4,887 & $30.7 \%$ \\
\hline
\end{tabular}

Table 13

Average Usage of Commitments to Lend

Asarnow and Marker (1995)

\begin{tabular}{|c|c|c|}
\hline $\begin{array}{c}\text { Credit Rating } \\
\text { Prior to Default }\end{array}$ & $\begin{array}{c}\text { Average Commitment } \\
\text { Usage }\end{array}$ & $\begin{array}{c}\text { Usage of normally unused } \\
\text { commitment in the event } \\
\text { of default }\end{array}$ \\
\hline AAA & $0.1 \%$ & $69 \%$ \\
\hline AA & $1.6 \%$ & $73 \%$ \\
\hline A & $4.6 \%$ & $71 \%$ \\
\hline BBB & $20.0 \%$ & $65 \%$ \\
\hline BB & $46.8 \%$ & $52 \%$ \\
\hline B & $63.7 \%$ & $48 \%$ \\
\hline CC & $75.0 \%$ & $44 \%$ \\
\hline
\end{tabular}


Figure 1

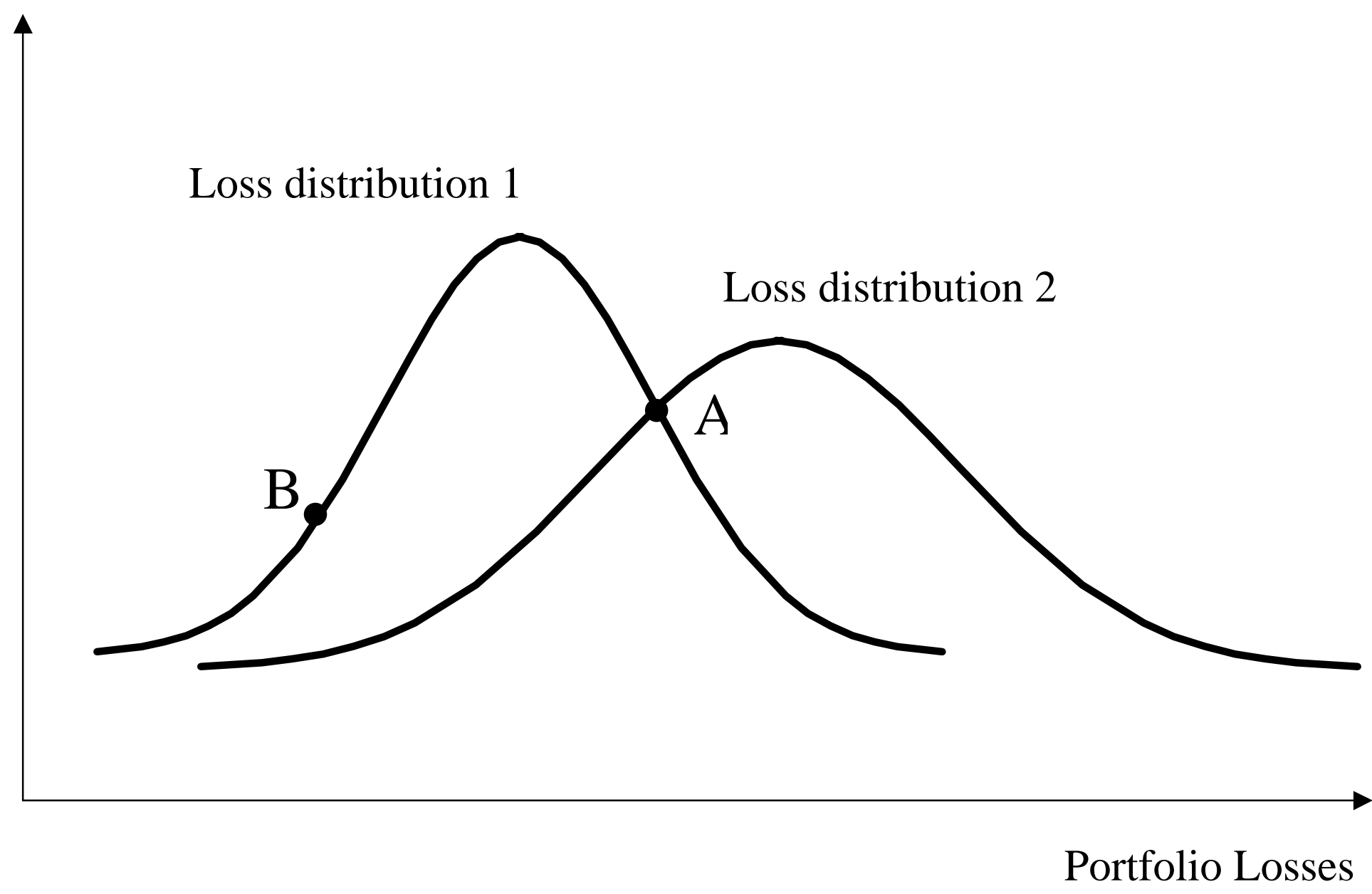


Figure 2

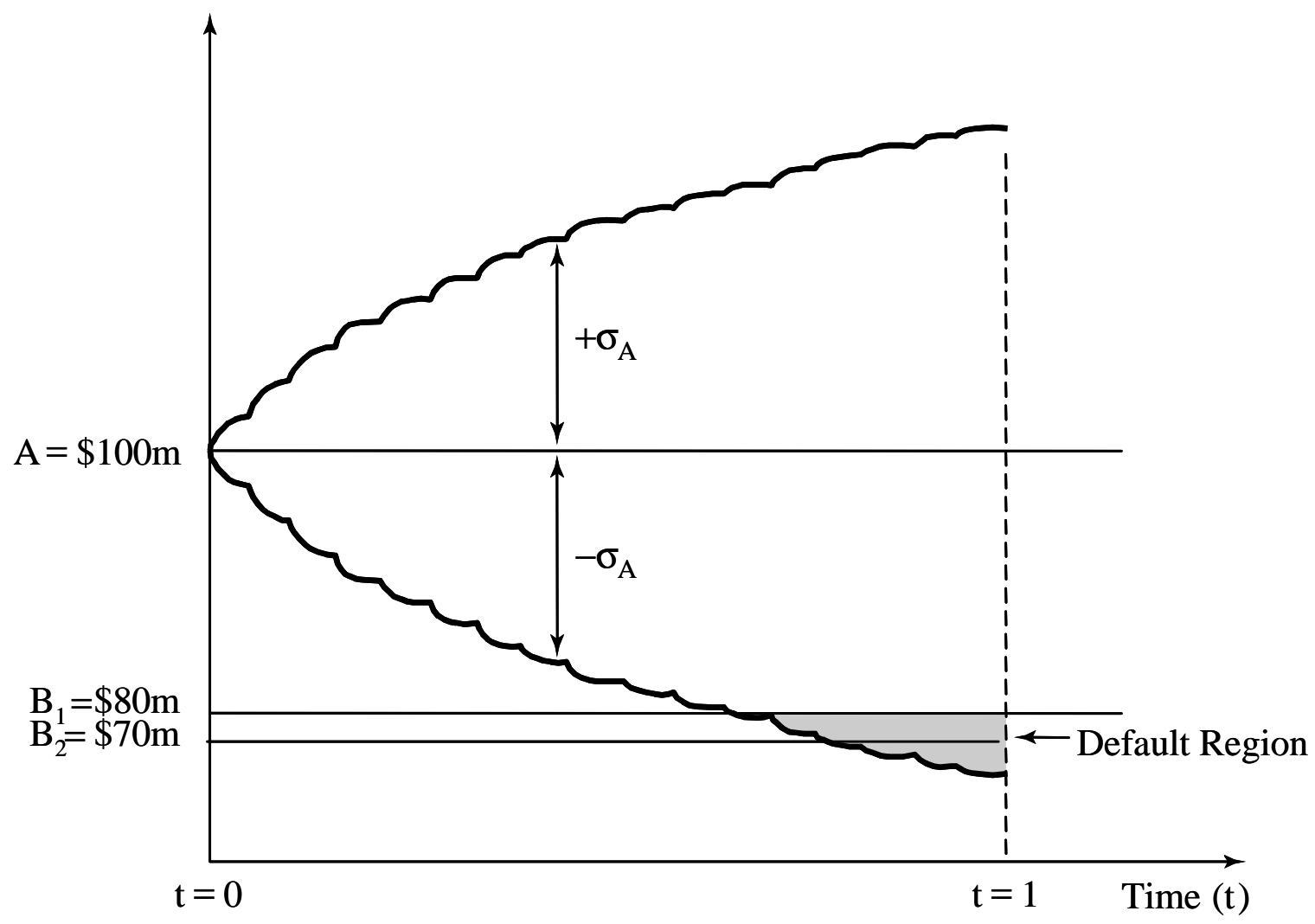


Figure 3, Panel A

Assets

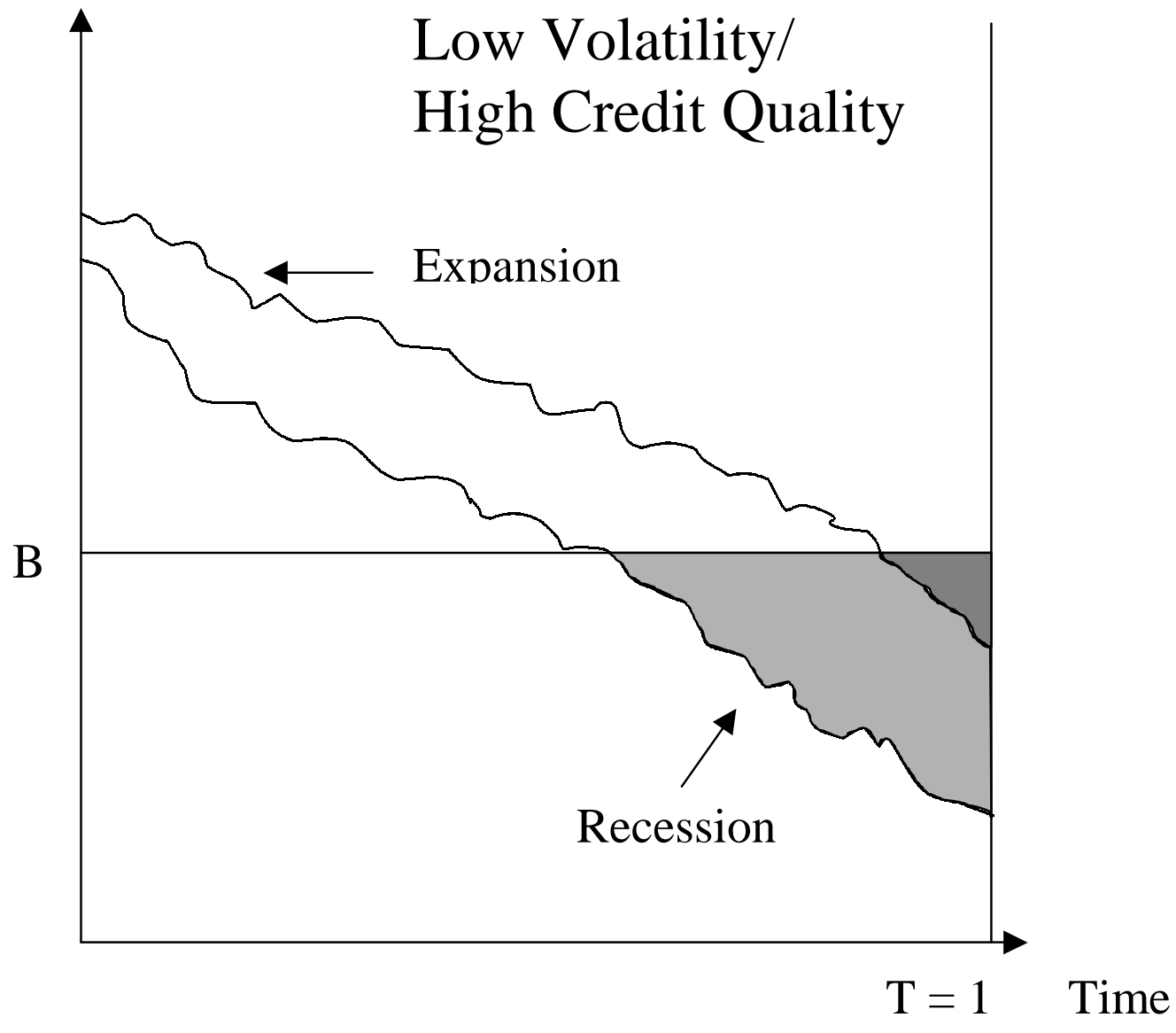


Figure 3, Panel B

Assets

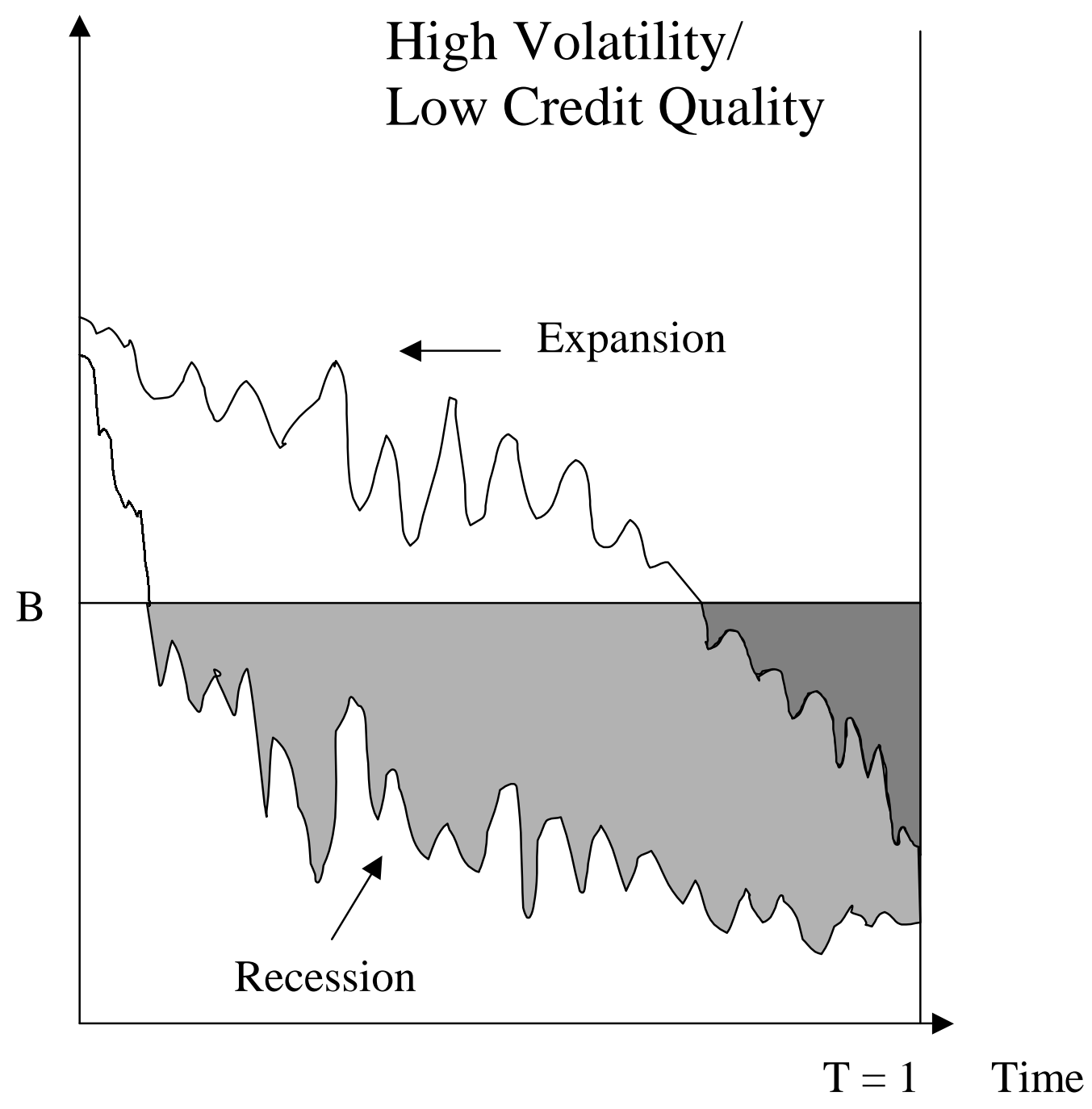


Figure 4

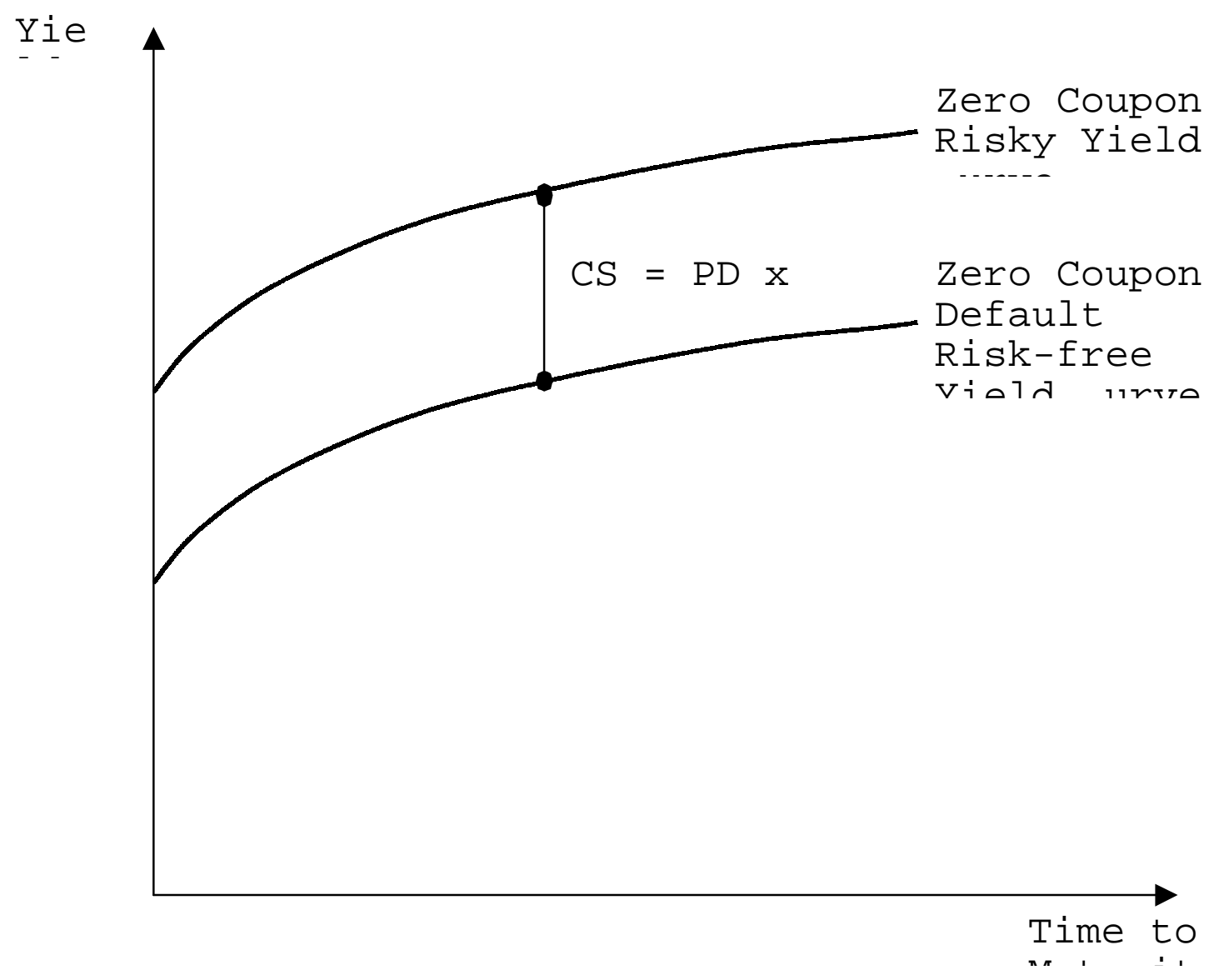




\section{References}

Allen, L., J. Jagtiani and Y. Landskroner, "Interest Rate Risk Subsidization in International Bank Capital Requirements," Journal of Economics and Business, August 1996, 48, 251-267.

Altman, E.I., Distressed Securities, Burr Ridge: Irwin Publishing, 1991 (reprinted by Beard Books, 1999).

Altman, E.I., with P. Arman, "Defaults and Returns on High Yield Bonds: Analysis Through the First Quarter 2002," Salomon Center Working Paper, April 2002.

Altman, E.I., with B. Brady, "Explaining Aggregate Recovery Rates on Corporate Bond Defaults," Salomon Center Working Paper, November 2001.

Altman, E.I., A. Resti and A. Sironi, "Analyzing and Explaining Default Recovery Rates,” ISDA Resport, December 2001.

Altman, E.I. and V. Kishore, "Almost Everything You Wanted to Know About Recoveries on Defaulted Bonds," Financial Analysts Journal, 1996, vol. 52, no. 6, pp. $57-64$

Altman, E.I., "Measuring Corporate Bond Mortality," Journal of Finance, September 1989, vol. 44, no. 4, pp. 90-922.

Anderson, R., S. Sundaresan, and P. Tychon, "Strategic Analysis of Contingent Claims." European Economic Review, April 1996, pp. 871-881.

Anderson, R. and S. Sundaresan, "A Comparative Study of Structural Models of Corporate Bond Yields: An Exploratory Investigation," Journal of Banking and Finance, vol. 24 (2000), pp. 255-269.

Asarnow, E. and J. Marker, "Historical Performance of the US Corporate Loan Market 1988-1993," Journal of Commercial Lending, vol. 10, no. 2, Spring 1995, pp. 13-32.

Bakshi, G., D. Madan, and F. Zhang, "Investigating the Sources of Default Risk: Lessons from Empirically Evaluating Credit Risk Models," University of Maryland working paper, February 28, 2001.

Bangia, A., F.X. Diebold, T. Schuermann, "Ratings Migration and the Business Cycle, With Applications to Credit Portfolio Stress Testing." Wharton Financial Institutions Center, Working Paper 26, April 2000. 
Bank for International Settlements, "Marrying the Macro- and Microprudential Dimensions of Financial Stability,” BIS Papers No. 1, March 2001.

Barnhill, T.M., Jr., and W. F. Maxwell, "Modeling Correlated Interest Rate, Spread Risk, and Credit Risk for Fixed Income Portfolios." June 2001, Journal of Banking and Finance, (forthcoming).

Belkin, B., S. Suchower, and L.R. Forest, "The Effect of Systematic Credit Risk on Loan Portfolio Value-at-Risk and Loan Pricing," CreditMetrics Monitor, First Quarter 1998, pp. 17-28.

Berger, A.N. and G.F. Udell, "Institutional Memory, the Business Cycle and Bank Lending Behavior," Presented at the Conference on Changes in Risk through Time: Measurement and Policy Options, March 6, 2002.

Berger, A.N. and G.F. Udell, "Did Risk-Based Capital Allocate Bank Credit and Cause a 'Credit Crunch' in the United States?' Journal of Money, Credit and Banking, vol. 26, 1994, pp. 585-628.

Bernanke, B.S. and C.S. Lown, "The Credit Cturnch," Brookings Papers on Economic Activity, No. 2, 1991, pp. 205-248.

Bhansali, V. and M.B. Wise, "Forecasting Portfolio Risk in Normal and Stressed Markets," Journal of Risk, Fall 2001, vol. 4, no. 1, pp. 91-106.

Borio, C., C. Furfine, and P. Lowe, "Procyclicality of the Financial System and Financial Stability: Issues and Policy Options,” BIS working paper, February 2001.

Borio, C. and P. Lowe, "Asset Prices, Financial and Monetary Stability: Exploring the Nexus,” BIS working paper, January 7, 2002.

Carey, M., "Credit Risk in Private Debt Portfolios." Journal of Finance, August 1998, pp. 1363-1387.

Cavallo, M., and G. Majnoni, "Do Banks Provision for Bad Loans in Good Times? Empirical Evidence and Policy Implications." World Bank, Working Paper 2691, June 2001.

Chang, G. and S.M. Sundaresan, "Asset Prices and Default-Free Term Structure in an Equilibrium Model of Default." Columbia University Working Paper, October 1999.

Chiuri, M.C., G. Ferri, and G. Majnoni, “The Macroeconomic Impact of Bank Capital Requirements in Emerging Economies: Past Evidence to Assess the Future," Journal of Banking and Finance, vol. 26, 2002, pp. 881-904. 
Collin-Dufresne, P. and B. Solnik, "On the Term Structure of Default Premia in the Swap and LIBOR Markets.” Journal of Finance, June 2001, pp. 1095-1115.

Collin-Dufresne, P. and Goldstein, R., "Do Credit Spreads Reflect Stationary Leverage Ratios?” Journal of Finance, October 2001, vol. LVI, no. 5, pp. 1929-1957.

Collin-Dufresne, P., Goldstein, R. and J.S. Martin, "The Determinants of Credit Spreads Changes" Journal of Finance, December 2001, vol. LVI, no. 6, pp. 2177-2207

Crouhy, M., D. Galai, and R. Mark, "Prototype Risk Rating System.” Journal of Banking and Finance, January 2001, pp. 47-95.

Crouhy, M., D. Galai, and R. Mark, "A Comparative Analysis of Current Credit Risk Models." Journal of Banking and Finance, January 2000, pp. 57-117.

Dalianes, P.C. "Credit Risk Pricing: Summary and Current Methodology," Quantitative Models in Finance, 1999.

Das, S.R., L. Freed, G. Geng, N. Kapadia, "Correlated Default Risk," September 14, 2001 Working Paper, Santa Clara University.

Das, S.R., G. Fong, G. Geng. "The Impact of Correlated Default Risk on Credit Portfolios," September 14, 2001 Working Paper, Santa Clara University.

Duffee, G.R., "Estimating the Price of Default Risk." The Review of Financial Studies, Spring 1999, pp. 197-226

Duffie, D. and K.J. Singleton, "Modeling the Term Structures of Defaultable Bonds," Review of Financial Studies, 1999, vol. 12, pp. 687-720.

Duffie, D., and K.J. Singleton, "Simulating Correlated Defaults." Paper presented at the Bank of England Conference on Credit Risk Modeling and Regulatory Implications, London, September 21-22,1998.

Duffie, D. and Lando, D., "Term Structures of Credit Spreads with Incomplete Accounting Information," Econometrica, vol. 69, 2001, pp. 663-664.

Erlenmaier, U. and H. Gersbach, "Default Probabilities and Default Correlations," February 2001 Working Paper, University of Heidelberg, February 2001.

Estrella, A., "The Cyclical Behavior of Optimal Bank Capital," Federal Reserve Bank of New York Working Paper, December 2001.

Falkenheim, M. and A. Powell, "The Use of Credit Bureau Information in the Estimation of Appropriate Capital and Provisioning Requirements." Central Bank of Argentina, Working Paper, 2001. 
Fama, E., "Term Premiums and Default Premiums in Money Markets," Journal of Financial Economics, 1986, vol. 17, np. 1, pp. 175-196.

Ferri, G., L.G. Liu, and G. Majnoni, "The Role of Rating Agency Assessments in Less Developed Countries: Impact of the Proposed Basel Guidelines." Journal of Banking and Finance, January 2001, pp. 115-148.

Finger, C.C., "Conditional Approaches for CreditMetrics Portfolio Distributions." Riskmetrics Monitor, April 1999.

Fridson, M., C. Garman, and S. Wu, "Real Interst Rates and the Default Rates on HighYield Bonds," Journal of Fixed Income, September 1997, pp. 27-34.

Frye, J., “Collateral Damage,” Risk, April 2000a, 91-94.

Frye, J., "Depressing Recoveries," Risk, November 2000b, 108-111.

Gersbach, H. and U. Wehrspohn, "Lean IRB Approaches and Transition Design: The Basel II Proposal,” University of Heidlberg working paper, October 2001.

Geyer, A., S. Kossmeier, and S. Pichler, "Empirical Analysis of European Government Yield Spreads,” Vienna University of Technology Working Paper, March 2001.

Goodhart, C., "Price Stability and Financial Fragility," in K. Sawamoto, Z. Nakjima and H. Taguchi, eds., Financial Stability in a Changing Environment, St. Martin's Press, 1995.

Gordy, M., "A Risk Factor Model Foundation for Ratings-Based Bank Captial Rules," Board of Governors of the Federal Reserve System Working Paper, February 2001.

Gupton, G.M., D. Gates and L.V. Carty, "Bank-Loan Loss Given Default," Moody's Investors Service, Global Credit Research, November 2000.

Hancock, D. and J.A. Wilcox, "Was There a 'Capital Crunch' in Banking? The Effects on Real Estate Lending of Business Conditions and Capital Shortfalls," Journal of Housing Economics, vol. 3, no. 1, December 1993, pp. 75-105.

Hancock, D. and J.A. Wilcox, "Bank Balance Sheet Shocks: Are There Dynamic Effects on Bank Capital and Lending?" Journal of Banking and Finance, vol. 19, 1995, pp. 661677.

Hofmann, B., “The Determinants of Private Sector Credit in Industrialised Countries: Do Property Prices Matter," Bank for International Settlements Monetary and Economic Department working paper, December 2001. 
Houweling, P., and T. Vorst, "An Empirical Comparison of Default Swap Pricing Models," Erasmus University working paper, December 21, 2001.

Hull, J. and A. White, "The Impact of Default Risk on the Prices of Options and Other Derivative Securities," Journal of Banking and Finance, 1995, vol. 19, pp. 299-322.

Jackson, P., W. Perraudin, and V. Saporta, "Setting Minimum Capital for Internationally Active Banks." Paper presented at the Bank of England Conference on Banks and Systemic Risk, London, May 23-25, 2001.

Jarrow, R.A., "Default Parameter Estimation Using Market Prices." Financial Analysts Journal, September/October 2001, pp. 75-92.

Jarrow, R.A. and F. Yu, "Counterparty Risk and the Pricing of Defaultable Securities," Journal of Finance, October 2001, 1765-1799.

Jarrow, R.A., Van Deventer, D.R., X. Wang, “A Robust Test of Merton's Structural Model for Credit Risk,” Kamakura Corporation working paper, April 21, 2002.

Jokivuolle, E. and S. Peura, "Incorporating Collateral Value Uncertainty in Loss-GivenDefault Estimates and Loan-to-Value Ratios," Bank of Finland Discussion Papers $2 / 2000$.

Jordan, J., J. Peek, and E. Rosengren, "Credit Risk Modeling and the Cyclicality of Capital,” BIS conference, March 6, 2002.

Kim, J., "Conditioning the Transition Matrix." Credit Risk, October 1999, pp. 37-40.

Kim, I.J., K. Ramaswamy, S. Sundaresan, "Does Default Risk in Coupons Affect the Valuation of Corporate Bonds? A Contingent Claims Model," Financial Management, 1993, vol. 22, no. 3, pp. 117-131.

Lando, D., "On Cox Processes and Credit Risky Securities," Review of Derivatives Research, 1998, vol. 2, pp. 99-120.

Leland, H., "Corporate Debt Value, Bond Covenants and Optimal Capital Structure." Journal of Finance, September 1994, pp. 1213-1252.

Longin, F., and B. Solnik, "Extreme Correlation of International Equity Markets," Journal of Finance, April 2001, vol. LVI, no. 2, pp. 649-676.

Longstaff, F.A., and E.F. Schwartz, "A Simple Approach to Valuing Risky Fixed and Floating Rate Debt." Journal of Finance, July 1995, pp.789-819. 
Lown, C.S., and D.P. Morgan, "The Credit Cycle and the Business Cycle: New Findings Using the Survey of Senior Loan Officers." Federal Reserve Bank of New York, Working Paper, June 25, 2001.

Lown, C.S. and S. Peristiani, "The Behavior of Consumer Loan Rates During the 1990 Credit Slowdown," Journal of Banking and Finance, vol. 20, 1996, pp. 1673-1694.

Maclachlan, I., "Recent Advances in Credit Risk Management." Ninth Melbourne Money and Finance Conference, June 19, 1999.

Madan, D.B. and H. Unal, "A Two-Factor Hazard-Rate Model for Pricing Risky Debt and the Tern Structure of Credit Spreads." Journal of Financial and Quantitative Analysis, March 2000, pp.43-65.

Mei, J. and A. Saunders, "Have US Financial Institutions' Real Estate Investments Exhibited "Trend Chasing" Behavior?" The Review of Economics and Statistics, 1997, pp. 248-258.

Mella-Barral, P., and W. Perraudin, "Strategic Debt Service."' Journal of Finance, June 1997, pp. 531-556.

Monfort, B. and C. Mulder, "Using Credit Ratings for Capital Requirements on Lending to Emerging Market Economies - Possible Impact of a New Basel Accord ."International Monetary Fund, Working Paper WP/00/69, 2000.

Mueller, C., "A Simple Multi-Factor Model of Corporate Bond Prices." Doctoral Dissertation University of Wisconsin-Madison, October 29, 2000.

Nickell, P., W. Perraudin, and S. Varotto, "Stability of Rating Transitions." Journal of Banking and Finance, vol. 24 no. 1/2, 2000, pp. 203-228.

Peek, J. and E.S. Rosengren, "The Capital Crunch: Neither a Borrower Nor a Lender Be," Journal of Money, Credit and Banking, vol. 27, no. 3, August 1995, pp. 625-638.

Pulvino, T.C., "Do Asset Fire Sales Exist? An Empirical Investigation of Commercial Aircraft Transactions," Journal of Finance, June 1998, vol. LIII, no. 3, pp. 939-978.

Purhonen, M., "New Evidence of IRB Volatility," Risk, March 2002, pp. S21-S25.

Pykhtin, M. and A. Dev, "Analytical Approach to Credit Risk Modeling," Risk, March 2002, pp. S26-S32.

Reisen, H., "Revisions to the Basel Accord and Sovereign Ratings." in R. Hausmann and U. Hiemenz (eds.), Global Finance From a Latin American Viewpoint, IDB/OECD Development Centre, 2000. 
Saunders, A., "Comments on 'The Macroeconomic Impact of Bank Capital Requirements in Emerging Economies: Past Evidence to Assess the Future," Journal of Banking and Finance, vol. 26, 2002, pp. 905-907.

Saunders, A. and L. Allen, Credit Risk Measurement: New Approaches to Value at Risk and Other Paradigms, New York: John Wiley and Sons, 2002.

Unal, H., D. Madan, and L. Guntay, "A Simple Approach to Estimate Recovery Rates with APR Violation from Debt Spreads." Wharton Financial Institutions Center, Working Paper 7, February 2001, Journal of Banking and Finance, forthcoming.

Wilson, T., "Credit Risk Modeling: A New Approach." New York: McKinsey Inc., 1997a (mimeo).

Wilson, T., "Portfolio Credit Risk (Parts I and II)." Risk Magazine, September and October, 1997b.

Zhou, C., "An Analysis of Default Correlations and Multiple Defaults." The Review of Financial Studies, Summer 2001, pp. 555-576. 